Article

\title{
Phylogeny and Biogeography of Branchipolynoe (Polynoidae, Phyllodocida, Aciculata, Annelida), with Descriptions of Five New Species from Methane Seeps and Hydrothermal Vents
}

\author{
Johanna Lindgren ${ }^{1}$, Avery S. Hatch ${ }^{1}$, Stephané Hourdez ${ }^{2}$, Charlotte A. Seid $^{1}$ (D) and \\ Greg W. Rouse ${ }^{1, * \mathbb{D}}$ \\ 1 Scripps Institution of Oceanography, University of California San Diego, La Jolla, CA 92093-0202, USA \\ 2 Observatoire Oceanologique de Banyuls-sur-Mer, UMR 8222 CNRS-SU, 1 avenue Pierre Fabre, 66650 \\ Banyuls-sur-Mer, France \\ * Correspondence: grouse@ucsd.edu; Tel.: +1-858-534-7973 \\ http://zoobank.org/urn:lsid:zoobank.org:pub:762D2B98-C1BA-4C28-97EB- \\ D797CB99893F \\ check for \\ updates
}

Received: 2 August 2019; Accepted: 27 August 2019; Published: 31 August 2019

\begin{abstract}
The four named species of Branchipolynoe all live symbiotically in mytilid mussels (Bathymodiolus) that occur at hydrothermal vents or methane seeps. Analyses using mitochondrial (COI and 16S) and nuclear (ITS) genes, as well as morphology, were conducted on a collection of Branchipolynoe from Pacific Costa Rican methane seeps and West Pacific hydrothermal vents. This revealed five new species of Branchipolynoe, and these are formally described. The new species from Costa Rica live in three species of Bathymodiolus mussels (also new) at depths ranging from 1000 to $1800 \mathrm{~m}$. Branchipolynoe kajsae n. sp. and Branchipolynoe halliseyae n. sp. were found in all three undescribed Bathymodiolus species, while Branchipolynoe eliseae n. sp. was found in Bathymodiolus spp. 1 and 2, and Branchipolynoe meridae n. sp. was found in Bathymodiolus spp. 1 and 3. Hence, Bathymodiolus sp. 1 hosted all four of the new species, while the other two Bathymodiolus hosted three each. Most mussels contained only one specimen of Branchipolynoe; where there was more than one, these were often a female and smaller male of the same species. The newly discovered species from the West Pacific, Branchipolynoe tjiasmantoi n. sp., lives in unidentified Bathymodiolus at depths ranging from 674 to $2657 \mathrm{~m}$ from hydrothermal vents in the North Fiji (Fiji) and Lau Basins (Tonga) and also from New Zealand, Vanuatu, and the Manus Basin (Papua New Guinea). The phylogenetic and biogeographical implications of this diversity of Branchipolynoe are discussed.
\end{abstract}

Keywords: deep sea; taxonomy; Pacific Ocean; chemosynthetic environment; methane seep

\section{Introduction}

Scale worms refers to a variety of family-ranked taxa (e.g., Polynoidae Kinberg 1856, Sigalionidae Kinberg 1856) placed in Aphroditiformia, which is a relatively large clade of annelids within Phyllodocida [1-3]. In terms of species richness, Polynoidae is the most diverse of these families, with more than 850 accepted species [4], and these are grouped into many subfamilies. Currently there are 18 named polynoid species that have segmental branchiae. These belong to five genera spread across several subfamilies: Branchinotogluma Pettibone, 1985 [5], Branchiplicatus Pettibone, 1985 [6], Branchipolynoe Pettibone, 1984 [7], Peinaleopolynoe Desbruyères \& Laubier, 1988 [8], and Thermopolynoe Miura, 1994 [9]. All are found in the deep sea at hydrothermal vents, methane seeps, or whale falls. Branchipolynoe contains species that are only found living inside mussel mantle cavities. Notably, they have very well-developed branchiae, much larger than the other branchiate polynoid species. 
These branchiae do not contain blood vessels but are instead filled with coelomic fluid that circulates throughout the body cavity and contains extracellular hemoglobins, producing their red color [10]. Branchipolynoe are also unusual for their small scales, since most scale worms have scales that completely cover the dorsum.

Branchipolynoe species have been historically regarded as inquiline symbionts because they did not appear to cause any noticeable harm to the host mussels [7]. However, recent studies have suggested that they may be parasitic [11-14]. As well as consuming their hosts, Branchipolynoe also cause tissue damage and stunt growth. Infected mussels have been found to have damaged gill filaments [15] as well as deformed labial palps and feet [13]. Branchipolynoe cf. seepensis, from the Mid-Atlantic Ridge, has been demonstrated to be sexually dimorphic, with larger females, and show a sex ratio ranging from 1.4:1 to 2:1 in favor of females. Also, females were shown to have two pairs of nephridial papillae and males only one pair $[16,17]$. The skewed sex ratio and dimorphism were confirmed also for $B$. cf. seepensis from eastern Atlantic cold seeps [18]. This corresponds with their behavior, as females will remain in their host mussel their whole life and males must leave their host mussel to find females [14]. Branchipolynoe cf. seepensis shows internal fertilization, and the females can store sperm and are able to produce many offspring from one pairing $[14,16]$. Their fecundity is limited by their very large (up to $400 \mu \mathrm{m}$ ), likely lecithotrophic eggs [17]. It should be noted that in none of the formal taxonomic descriptions of Branchipolynoe has any sexual dimorphism, in terms of numbers of pairs of elongated ventral papillae, been noted. In all cases, two pairs of such papillae have only been reported [7,19-21], on Segments 11 and 12.

Branchipolynoe presently has four named species [7,19-21]. Branchipolynoe symmytilida Pettibone, 1984, was described from Galapagos Rift hydrothermal vents [7,22] and lives in Bathymodiolus thermophilus Kenk \& Wilson, 1985. It has also been found at East Pacific Rise (EPR) vents [23,24] in the hosts Bathymodiolus thermophilus and B. antarcticus Johnson \& Vrijenhoek, 2013. While the EPR B. symmytilida and Galapagos B. symmytilida show some genetic differentiation, in terms of haplotype frequency distribution [24], there is no doubt that it is a widely-distributed species. Branchipolynoe pettiboneae Miura \& Hashimoto, 1991, was described from hydrothermal vents at the Kaikata Seamount (east of Japan) in the hosts Bathymodiolus brevior Cosel, Métivier \& Hashimoto, 1994, Gigantidas platifrons Hashimoto \& Okutani, 1994, and B. japonicus Hashimoto \& Okutani, 1994 [20,25]. It has also been recorded from vents at Izena Hole, Okinawa Trough $[20,26]$ and from a cold seep in the northern South China Sea [26]; specimens from both sites have been sequenced [3,27] and are the same species [27]. Branchipolynoe pettiboneae has also been reported from other vent areas in the western Pacific, including the North Fiji and Lau Basins $[23,25,28]$, though these records refer to one of the new species described here. Branchipolynoe longqiensis Zhou, Zhang, Lu \& Wang, 2017, was described from the Longqi vent field (Southwest Indian Ridge) in the host Bathymodiolus marisindicus Hashimoto [21]. Two sequences available from Indian Ocean hydrothermal vents for unnamed species of Branchipolynoe $[29,30]$ can be attributed to Branchipolynoe longqiensis (Zhou pers. comm., this study). Branchipolynoe seepensis Pettibone, 1986, was described from Florida Escarpment (Gulf of Mexico) methane seeps in an unidentified Bathymodiolus mussel [19]. The host mussel is most likely Bathymodiolus heckerae Gustafson, Turner, Lutz \& Vrijenhoek, 1998, from the Florida Escarpment [31]. Branchipolynoe seepensis has also been recorded several times from the Mid-Atlantic Ridge (MAR) [32-34]. There, it is found in hosts Bathymodiolus azoricus Cosel \& Comtet, 1999, and B. puteoserpentis Cosel, Métivier \& Hashimoto, 1994 [23,34,35]. However, the MAR Branchipolynoe seepensis and the Gulf of Mexico B. seepensis are likely separate species, based on three reasons. The prime reason is that the stated genetic distance for cytochrome c oxidase subunit I (COI) exceeds $5 \%$ between specimens from the two localities [23], though unfortunately the COI sequences are not available on GenBank. Second, the Gulf of Mexico and MAR localities are thousands of kilometers apart. Finally, one group (the true B. seepensis) is found at methane seeps, while the other (MAR group) is from hydrothermal vents [23].

In this paper, we present molecular sequence data from samples of Branchipolynoe from a series of Pacific Costa Rican methane seeps that have been explored in recent years [36,37], as well as from 
West Pacific hydrothermal vents (North Fiji and Lau Basins and Vanuatu). We sequenced DNA for the mitochondrial COI and 16S rDNA loci, as well as the nuclear internal transcribed spacer (ITS) region (ITS1 + 5.8S rRNA + ITS2). We also document the varying anatomy of the worms. The phylogeny and biogeography of Branchipolynoe are assessed, and five new species are described. Phylogeographic patterns of the new Branchipolynoe species are also documented.

\section{Materials and Methods}

\subsection{Sampling}

Specimens of Bathymodiolus containing Branchipolynoe were collected from several cruises off Costa Rica from 2009-2017. There were three main sites ranging from 1000 to $1800 \mathrm{~m}$ depth (Table 1), and these were separated by a maximum distance of around $60 \mathrm{~km}$. Samples from Fiji (North Fiji Basin), New Zealand (Kermadec), Tonga (Lau Basin), and Vanuatu were collected from 2005-2013. A specimen of $B$. seepensis was collected from near the type locality (Florida Escarpment). We also sequenced several specimens of B. symmytilida from the EPR to obtain ITS sequences. Branchipolynoe specimens were fixed and preserved in $95 \%$ ethanol or fixed in $10 \%$ formalin before preservation in $50 \%$ ethanol, in accordance with accepted preservation and safety protocols at the Scripps Institution of Oceanography. A piece of the foot of Costa Rican host Bathymodiolus specimens was placed in $95 \%$ ethanol, and these taxa will be described elsewhere. Table 1 outlines the collection details for the Branchipolynoe used in this study for DNA sequencing. The holotypes, most paratypes, and vouchers are deposited at the Scripps Institution of Oceanography, Benthic Invertebrate Collection (SIO-BIC), La Jolla, California, USA. Paratypes are also deposited at the Museo de Zoología (Universidad de Costa Rica), San José, Costa Rica (MZUCR). Some vouchers are also deposited at the Muséum national d'Histoire naturelle (MNHN-IA), Paris, France. 
Table 1. Newly sequenced terminals, types/vouchers, and GenBank accession numbers. Sampling sites are as follows: German Flats, EPR $37.67 \mathrm{~S}, 110.88 \mathrm{~W}$ (2236 m); Choo Choo, EPR 9.82 N, 104.30 W (2518 m); Brothers Caldera, Kermadec, NZ 34.86 S, 179.06 E (1825 m); Florida Escarpment, GM 26.03 N, 84.91 W (3296 m); Haungaroa, Kermadec, NZ 32.61 S, 179.62 E (674 m); Jaco Scar, CR 9.12 N, 84.84 W (1800-1891 m); Lau Basin, Tonga 20.05 S, 176.13 E (2623-2657 m); Mound 12, CR 8.93 N, 84.31 W (999-1009 m); Nifonea Vent Field, Vanuatu 18.12 S, 169.51 E (1868-1873 m); Niuatahi Seamount, Tonga 15.40 S, 174.01 W (1576 m); Quepos Seep, CR 9.03 N, 84.62 W (1409 m); White Lady, Fiji 16.99 S, 173.91 E (1973-1991 m). General localities: CR = Costa Rica, EPR = East Pacific Rise, GM = Gulf of Mexico, NZ = New Zealand.

\begin{tabular}{|c|c|c|c|c|c|}
\hline Scientific Name & Site & COI & $16 S$ & ITS & Specimen: SIO-BIC (A), MZUCR, or MNHN (IA) \\
\hline \multirow[t]{2}{*}{$\begin{array}{l}\text { Branchipolynoe symmytilida } \\
\text { (type species) }\end{array}$} & German Flats, EPR & MH369876-77 & MH396821-22 & MH396787-88 & A6554-55 \\
\hline & Choo Choo, EPR & MH369875 & MH396823 & - & A6556 \\
\hline Branchipolynoe seepensis & $\begin{array}{l}\text { Florida Escarpment, } \\
\text { GM }\end{array}$ & MH369885 & MH596848 & - & A6553 \\
\hline \multirow{6}{*}{ Branchipolynoe kajsae n. sp. } & Jaco Scar, CR & MH369859-62 & $\begin{array}{l}\text { MH396799-800, } \\
\text { MH396811-12 }\end{array}$ & $\begin{array}{l}\text { MH396774, } \\
\text { MH396776, } \\
\text { MH396782-83 }\end{array}$ & A2159-62 \\
\hline & & MH369872-73 & MH396816, MH396819 & - & A6516, A6518 \\
\hline & & - & MH396817-18, MH396820 & - & A6517, A6519-20 \\
\hline & & MH369906-07, MH370018 & - & - & A6652, A6669, MZUCR 405-01 \\
\hline & Mound $12, \mathrm{CR}$ & MH369893, MH369899, MH369902, MH369939-41 & - & - & A6574, A6597, A6611, A6626, A6662, A6703 \\
\hline & Quepos Seep, CR & MH369923, MH369961, MH369983-84 & - & - & A6707, A6710, A6712-13 \\
\hline \multirow{6}{*}{ Branchipolynoe halliseyae n. sp. } & Mound $12, \mathrm{CR}$ & MH369853-56, MH369858, MH369870 & $\begin{array}{l}\text { MH396795, MH396801, } \\
\text { MH396803-04, MH396810, } \\
\text { MH396815 }\end{array}$ & $\begin{array}{l}\text { MH396775, } \\
\text { MH396777-81 }\end{array}$ & A6532-34, A6539-40, A6545 \\
\hline & & MH369845, MH369847-51, MH369857 & $\begin{array}{c}\text { MH396794, MH396797-98, } \\
\text { MH396805-06, } \\
\text { MH396808-09 }\end{array}$ & - & A2127-A2128, A6531, A6535-38 \\
\hline & & МH369869 & - & MH396786 & A6544 \\
\hline & & $\begin{array}{l}\text { MH369841-44, MH369846, MH369852, MH369868, } \\
\text { MH369871, MH369887-92, MH369894-98, } \\
\text { MH369900-01, MH369903-04, MH369909-13, } \\
\text { MH369915-22, MH369927-28, MH369938, } \\
\text { MH369960, MH369962-82, MH369985-370015, } \\
\text { MH370017, MH370019-22 }\end{array}$ & - & - & $\begin{array}{l}\text { A1322, A2144, A6530, A6541-43, A6546-47, A6558, } \\
\text { A6568, A6570, A6575, A6578, A6582-89, A6592-93, } \\
\text { A6595-96, A6603-10, A6612, A6620-25, A6627-34, } \\
\text { A6636-37, A6640-49, A6656-59, A6661, A6673-85, } \\
\text { A6687-702, A6704-05, MZUCR 404-01 }\end{array}$ \\
\hline & Jaco Scar, CR & $\begin{array}{c}\text { MH369886, MH369905, MH369926, MH369930-35, } \\
\text { MH369937 }\end{array}$ & - & - & $\begin{array}{c}\text { A6613, A6617, A6619, A6650-51, A6653-54, A6667, } \\
\text { A6670, A6672 }\end{array}$ \\
\hline & Quepos Seep, CR & MH369914, MH369924-25, MH369929 & - & - & A6706, A6708-09, A6711 \\
\hline
\end{tabular}


Table 1. Cont

\begin{tabular}{|c|c|c|c|c|c|}
\hline Scientific Name & Site & COI & $16 \mathrm{~S}$ & ITS & Specimen: SIO-BIC (A), MZUCR, or MNHN (IA) \\
\hline \multirow{7}{*}{ Branchipolynoe meridae n. sp. } & \multirow[t]{2}{*}{ Jaco Scar, CR } & MH369884 & MH396829 & MH396793 & A2131 \\
\hline & & MH369936 & - & - & A6616 \\
\hline & \multirow[t]{5}{*}{ Mound 12, CR } & MH369865 & MH396796 & MH396784 & A6529 \\
\hline & & MH369866 & MH396807 & - & A6521 \\
\hline & & - & MH396802, MH396813 & - & A6523, A6526 \\
\hline & & MH369863-64, MH369867, MH370016 & - & - & A6524-25, A6527, MZUCR 404-02 \\
\hline & & - & MH396814 & MH396785 & A6528 \\
\hline \multirow{4}{*}{ Branchipolynoe eliseae n. sp. } & \multirow[t]{3}{*}{ Jaco Scar, CR } & MH369878, MH369882-83 & MH396826-28 & $\begin{array}{c}\text { MH396789, } \\
\text { MH396791-92, }\end{array}$ & MZUCR 403-01, A6548, A6552 \\
\hline & & MH369879-80 & MH396824-25 & - & A6549-50 \\
\hline & & MH369881 & - & MH396790 & A6551 \\
\hline & Mound $12, \mathrm{CR}$ & MH369908 & - & - & A6660 \\
\hline \multirow{6}{*}{ Branchipolynoe tjiasmantoi $\mathrm{n}$. sp. } & White Lady, Fiji & MH369874, MH369943-46 & - & - & A4009-10, A4011A-B, A5460 \\
\hline & Lau Basin, Tonga & MH369947, MH982238-41 & MH396830 & - & A8511 \\
\hline & $\begin{array}{l}\text { Niuatahi Seamount, } \\
\text { Tonga } \\
\end{array}$ & MH982230-35 & & & A9392 \\
\hline & Nifonea, Vanuatu & $\begin{array}{l}\text { MH369942, MH369948-59, MH607403, } \\
\text { MH982243-46 }\end{array}$ & - & - & A7303A, A7309A-K, A7310B-C, IA-2013-406-08 \\
\hline & Haungaroa, NZ & MH982242 & - & - & IA-2013-340 \\
\hline & Brothers Caldera, NZ & MH982236-37 & & & IA-2013-338-39 \\
\hline
\end{tabular}




\subsection{Morphology}

Canon EOS Rebel digital cameras mounted on a Leica S8APO stereomicroscope or Leica DMR HC compound microscope were used for micrography. Helicon Focus v.4.2.8 (Helicon Soft Ltd., Kharkiv, Ukraine) was used to merge images to create stacked pictures.

\subsection{DNA Extraction, Amplification, and Sequencing}

Partial mitochondrial cytochrome c oxidase subunit I (COI) sequences were obtained for nearly 200 Branchipolynoe individuals from Costa Rica, Fiji, New Zealand, Tonga, and Vanuatu. Sequences were also obtained for one specimen of B. seepensis and three specimens of B. symmytilida (Table 1 ). This was used to identify the major clades of Branchipolynoe.

This gene fragment was used to identify the major clades of Branchipolynoe. Mitochondrial 16S rDNA (16S) and nuclear ITS1+5.8S rRNA+ITS2 (ITS) sequences were also sequenced for a subset of these Branchipolynoe specimens for phylogenetic analyses and to aid with species discrimination (Table 1). COI sequences were obtained for a series of Bathymodiolus specimens to confirm host identity (taxa will be described elsewhere).

DNA was extracted using the Zymo Research Genomic DNA ${ }^{\mathrm{TM}}$ Tissue MiniPrep Kit or the Zymo Research Quick-DNA ${ }^{\mathrm{TM}} 96$ Plus Kit (Zymo Research, CA, USA) following the manufacturer's protocol. Genes were amplified with a PCR mixture of $12.5 \mathrm{uL}$ of either Apex ${ }^{\mathrm{TM}}$ Taq RED Master Mix (Genesee Scientific, USA) or Conquest ${ }^{\mathrm{TM}}$ PCR Master Mix 1 (Lamba Biotech, USA), $8.5 \mathrm{uL}$ H2O, 1 uL of each primer, and 50-100 ng DNA. For Branchipolynoe, a $~ 700$ bp fragment of COI was amplified with the primers LCO1490 and HCO2198 [38] and the following protocol: $3 \mathrm{~min} 94{ }^{\circ} \mathrm{C} ; 5 \times\left(30 \mathrm{~s} 94{ }^{\circ} \mathrm{C}, 45 \mathrm{~s} 47^{\circ} \mathrm{C}\right.$, $\left.1 \mathrm{~min} 72{ }^{\circ} \mathrm{C}\right) ; 30 \times\left(30 \mathrm{~s} 94{ }^{\circ} \mathrm{C}, 45 \mathrm{~s} 52^{\circ} \mathrm{C}, 1 \mathrm{~min} 72{ }^{\circ} \mathrm{C}\right) ; 5 \min 72{ }^{\circ} \mathrm{C}$. A $500 \mathrm{bp}$ region of $16 \mathrm{~S}$ was amplified with the protocol: $3 \min 95^{\circ} \mathrm{C} ; 40 \times\left(40 \mathrm{~s} 95^{\circ} \mathrm{C}, 40 \mathrm{~s} 50{ }^{\circ} \mathrm{C}, 50 \mathrm{~s} 72{ }^{\circ} \mathrm{C}\right) ; 5 \min 72{ }^{\circ} \mathrm{C}$ and the primers 16Sarl and 16Sbrh [39]. Nuclear ITS1+5.8S rRNA+ITS2 was amplified with primers ITS18SFPOLY and POLY_28R [40,41] and the protocol: $4 \min 96^{\circ} \mathrm{C} ; 45 \times\left(30 \mathrm{~s} 94{ }^{\circ} \mathrm{C}, 30 \mathrm{~s} 48^{\circ} \mathrm{C}, 1 \min 72{ }^{\circ} \mathrm{C}\right) ; 8 \min 72{ }^{\circ} \mathrm{C}$, or just the ITS2 region was amplified with the primers POLY_ITS3F and POLY_28R [41] and the same protocol. For Bathymodiolus, a 500-600 bp fragment of COI was amplified with primers BathCO1-F and BathCO1-R [42] and the protocol: $2 \mathrm{~min} 94^{\circ} \mathrm{C} ; 5 \times\left(35 \mathrm{~s} 94{ }^{\circ} \mathrm{C}, 35 \mathrm{~s} 48{ }^{\circ} \mathrm{C}, 70 \mathrm{~s} 72{ }^{\circ} \mathrm{C}\right) ; 35 \times\left(35 \mathrm{~s} 94{ }^{\circ} \mathrm{C}\right.$, $35 \mathrm{~s} 52{ }^{\circ} \mathrm{C}, 70 \mathrm{~s} 72{ }^{\circ} \mathrm{C}$ ); $10 \mathrm{~min} 72{ }^{\circ} \mathrm{C}$. PCR products were purified using 2 uL ExoSAP-IT ${ }^{\mathrm{TM}}$ (USB Corporation, Ohio, USA) with the protocol of $20 \mathrm{~min} 37^{\circ} \mathrm{C} ; 15 \mathrm{~min} 80^{\circ} \mathrm{C}$, and then sent to Eurofins Genomics (Louisville, KY, USA) or Retrogen, Inc. (San Diego, CA, USA) for sequencing. Sequences were assembled with Geneious v. 7.1 .9 [43] and aligned using MAFFT v. 7 [44] via default settings.

\subsection{Phylogenetic Analysis and Species Delimitation}

A maximum likelihood (ML) phylogeny was generated for unique COI sequences from specimens acquired for this study, along with unique available Branchipolynoe COI sequences on GenBank. Additional B. symmytilida COI sequences were sourced from Hurtado et al. [24] and Plouviez et al. [45]. Sequences referred to as B. pettiboneae (GenBank Accession ITS $=$ KY753840, Mitochondrial $=$ KY753825, MG799393, MK694794-799) were sourced from Zhang et al. [3] and Van Audenhaege et al. [46]. The sequences MK694794-799 are arguably not of B. pettiboneae and instead belong to one of the new species described here, B. tjiasmantoi $\mathrm{n}$. sp. Sequences of B. longqiensis (AF39996, KY211993, KY753847, KY753826) were acquired from several sources [3,29,30]. Maximum parsimony (MP) and ML phylogenies were also generated for a concatenated COI, 16S, and ITS datasets for a cutdown selection of terminals representing each Branchipolynoe species. Aligned sequences for COI, 16S, and ITS were concatenated using SequenceMatrix v 1.8 [47]. Branchinotogluma japonicus was used as the outgroup for all the analyses based on previous phylogenetic results [3], and COI, 16S, and ITS1+5.5SrDNA+ITS2 were used for this species (GenBank Accession KY753824, KY753841).

ML analyses were performed using RAxML v.8.2.10 [48,49] on the COI data and the concatenated data partitioned by gene, using the model GTR + G. Support was assessed via a minimum of 1000 
thorough bootstrap replicates. A Bayesian inference (BI) analysis of the concatenated data partitioned by gene was also conducted using MrBayes v.3.2.6 [50]. Two independent Markov chain Monte Carlo (MCMC) searches were run for 20,000,000 generations. A burn-in of 0.1 was applied to each search, and the combined results were checked for stationarity. The majority-rule consensus tree was annotated with posterior probability node values. The MP analysis of concatenated data was conducted using

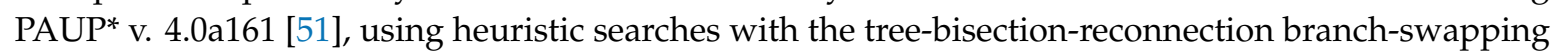
algorithm and 1000 random addition replicates. Support values were determined using 100 jackknife replicates each with 100 random addition searches, heuristic search with tree-bisection-reconnection, and character deletion set at $37 \%$.

To find the most suitable models for the BI analysis and for assessing genetic distances among and within Branchipolynoe species, jModelTest v. 2.1.4 [52,53] was implemented on the separate COI, 16S, and ITS datasets using the Akaike information criterion (AIC). The models selected were GTR + I $+\mathrm{G}$ for COI and $16 \mathrm{~S}$ and HKY+G for ITS. The uncorrected and model-corrected COI and ITS pairwise distances were generated using PAUP* v. 4.0a161. In addition to using the phylogenetic results and comparisons of genetic distance, we also used automated barcode gap definition (ABGD) [54] to assess species delineation for B. halliseyae n. sp. and B. kajsae n. sp. Settings used were Pmin 0.001 Pmax 0.1 with 10 steps, relative gap width 1.5, and 20 bins for distance distribution and the Kimura 2 (K80) model with a transition/transversion ratio (from jModeltest) of 2.4 for the COI dataset.

\subsection{Haplotype Networks and Population Genetics}

Haplotype networks for each species were obtained from COI data with PopART 1.1 [55], using the median joining network option with epsilon set to 0 . Trait-coded haplotype networks were made for each Costa Rican species, one for host mussels and one for depth. A locality-coded haplotype network was made for the West Pacific species. To assess any levels of genetic differentiation for several of the Branchipolynoe species, we performed analysis of molecular variance (AMOVA) in PopART on those with reasonable sample sizes (B. halliseyae n. sp., B. kajsae n. sp. and B. tjiasmantoi n. sp.). The significance of the $\phi_{\mathrm{ST}}$ values was assessed by a permutation test with 1000 replicates. These involved hosts and depths for the Costa Rican species and geography for B. tjiasmantoi n. sp.

\subsection{Character Transformations}

Character transformations for locality and habitat were performed using Mesquite v. 3.5 [56] on the phylogeny obtained from the combined COI, 16S, and ITS data. The Mk1 model was used for the transformations [57] as this incorporates branch length information into the transformation.

The characters and states used were

Locality: 0. East Pacific; 1. West Pacific; 2. Atlantic; 3. Indian.

Habitat: 0. Hydrothermal vents and 1. Methane seeps.

For most species the habitat is uniform, either vent or seep, but for B. pettiboneae the habitat was coded as vents or seeps $[3,27]$. We did not consider records for B. seepensis from the Mid-Atlantic Ridge (see Introduction) as being the same species as B. seepensis from the seep on the Florida Escarpment, so we coded this species as a seep dweller.

\section{Results}

\subsection{Species Delimitation and Phylogeny}

The ML phylogeny of all available unique COI sequences provides initial support for the recognition of five new species: Branchipolynoe eliseae n. sp., B. halliseyae n. sp., B. kajsae n. sp., and B. meridae n. sp. from Costa Rica and B. tjiasmantoi n. sp. from the West Pacific (Figure 1). These are formally described in Section 5. Taxonomy. Both the COI and ITS pairwise distances show much higher interspecific distances than intraspecific distances for each proposed new species (Tables 2 and 3). 
COI and ITS distances between Branchipolynoe meridae n. sp. and B. eliseae n. sp. were $8.5 \%$ and $5.5 \%$, respectively (Tables 2 and 3). Their COI distances to the EPR B. symmytilida were $10.1 \%$ and $11.8 \%$, respectively. Interestingly, the ITS distance from B. meridae n. sp. to B. symmytilida was $1.6 \%$, while for B. eliseae n. sp. this value was $4.8 \%$. The COI and ITS distances between B. kajsae n. sp. and B. halliseyae n. sp. were small at $4.5 \%$ (uncorrected $=3.7 \%$ ) and $2.7 \%$, respectively (Tables 2 and 3 ). Of the 144 individuals sequenced, a total of 132 unique COI sequences were obtained for these two species (113 for B. halliseyae n. sp. and 19 for B. kajsae n. sp.), and they formed reciprocally monophyletic sister groups (Figure 1). Branchipolynoe kajsae n. sp. showed a larger maximum intraspecific COI variation of $3 \%$, while for B. halliseyae n. sp. this was $1.9 \%$. Owing to this close relationship, and to further explore if they should be regarded as separated species, we sequenced further $16 \mathrm{~S}$ and ITS sequences for a range of individuals of $B$. halliseyae n. sp. and B. kajsae n. sp.; they again formed reciprocally monophyletic sister groups (Figure 2a).

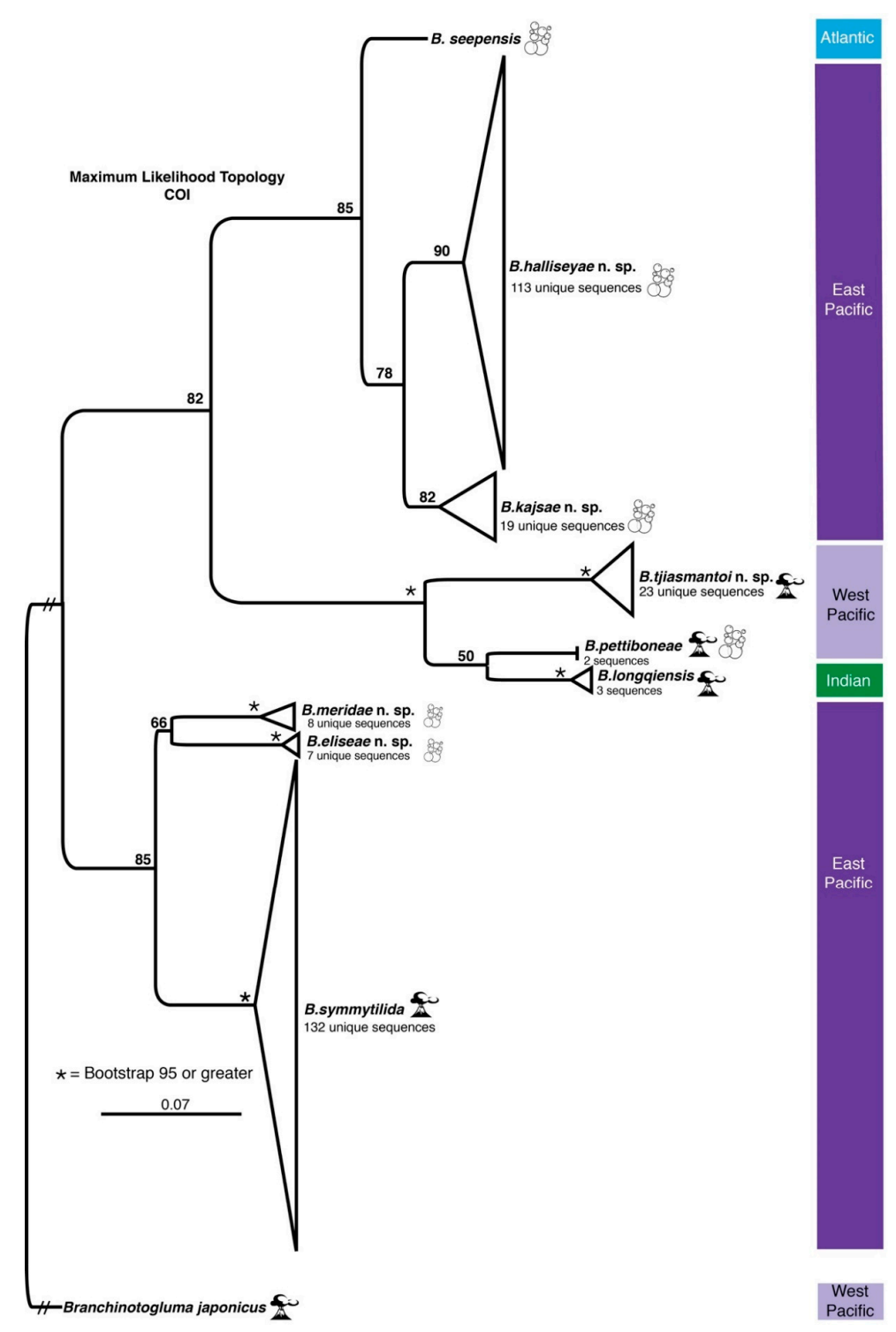

Figure 1. Maximum likelihood tree from the unique Branchipolynoe COI sequences from each of the five new species from this study and GenBank, a total of 309 sequences, rooted with Branchinotogluma japonicus. The variation within each species is collapsed. Support on relevant nodes are bootstrap values. Asterisk, ${ }^{*}$, indicates $95 \%$ or greater. 
Table 2. Minimum uncorrected interspecific distances (lower diagonal series) and minimum GTR+I+G corrected interspecific distances (upper diagonal series, italics) for Branchipolynoe species COI data. The maximum uncorrected intraspecific COI distances, where available, are shown as the diagonal, bold. Underlined distances are discussed in the text.

\begin{tabular}{cccccccccc}
\hline & $\mathbf{1}$ & $\mathbf{2}$ & $\mathbf{3}$ & $\mathbf{4}$ & $\mathbf{5}$ & $\mathbf{6}$ & $\mathbf{7}$ & $\mathbf{8}$ & $\mathbf{9}$ \\
\hline 1. B. symmytilida & $\mathbf{0 . 0 2 2}$ & 0.307 & 0.317 & 0.267 & $\underline{0.101}$ & $\underline{0.118}$ & 0.356 & 0.412 & 0.419 \\
2. B. seepensis & 0.136 & - & $\underline{0.072}$ & $\underline{0.080}$ & 0.306 & 0.272 & 0.396 & 0.368 & 0.375 \\
3. B. kajsae n. sp. & 0.132 & $\underline{0.053}$ & $\mathbf{0 . 0 3 0}$ & $\underline{0.045}$ & 0.247 & 0.301 & 0.335 & 0.359 & 0.347 \\
4. B. halliseyae n. sp. & 0.139 & $\underline{0.057}$ & $\underline{0.037}$ & $\underline{\mathbf{0 . 0 1 9}}$ & 0.325 & 0.310 & 0.404 & 0.338 & 0.437 \\
5. B. meridae n. sp. & $\underline{0.075}$ & 0.151 & $\underline{0.128}$ & 0.141 & $\mathbf{0 . 0 2 3}$ & $\underline{0.085}$ & 0.387 & 0.382 & 0.376 \\
6. B. eliseae n. sp. & $\underline{0.082}$ & 0.131 & 0.139 & 0.137 & $\underline{0.065}$ & $\mathbf{0 . 0 0 6}$ & 0.413 & 0.302 & 0.302 \\
7. B. tjiasmantoi n. sp. & 0.151 & 0.141 & $\underline{0.136}$ & $\underline{0.141}$ & $\underline{0.154}$ & $\underline{0.157}$ & $\mathbf{0 . 0 1 7}$ & $\underline{0.155}$ & $\underline{0.149}$ \\
8. B. pettiboneae & 0.155 & 0.133 & 0.132 & 0.129 & 0.147 & 0.140 & $\underline{0.096}$ & $\mathbf{0 . 0 3 2}$ & $\underline{0.089}$ \\
9. B. longqiensis & 0.156 & 0.140 & 0.135 & 0.142 & 0.154 & 0.157 & $\underline{0.091}$ & $\underline{0.064}$ & $\mathbf{0 . 0 1 1}$ \\
\hline
\end{tabular}

Table 3. Minimum uncorrected interspecific distances (lower diagonal) and minimum HKY $+\mathrm{G}$ corrected interspecific distances (upper diagonal, italics) for Branchipolynoe species ITS data. There are no data for B. seepensis or B. tjiasmantoi n. sp. Underlined distances are discussed in the text.

\begin{tabular}{cccccccc}
\hline & $\mathbf{1}$ & $\mathbf{2}$ & $\mathbf{3}$ & $\mathbf{4}$ & $\mathbf{5}$ & $\mathbf{6}$ & $\mathbf{7}$ \\
\hline 1. B. symmytilida & - & 0.169 & 0.147 & $\underline{0.016}$ & $\underline{0.048}$ & 0.151 & 0.173 \\
2. B. kajsae n. sp. & 0.126 & - & $\underline{0.027}$ & 0.215 & 0.201 & 0.260 & 0.255 \\
3. B. halliseyae n. sp. & 0.113 & $\underline{0.026}$ & - & 0.188 & 0.195 & 0.229 & 0.215 \\
4. B. meridae n. sp. & $\underline{0.016}$ & 0.149 & 0.137 & - & $\underline{0.055}$ & 0.249 & 0.246 \\
5. B. eliseae n. sp. & $\underline{0.044}$ & 0.141 & 0.139 & $\underline{0.049}$ & - & 0.271 & 0.337 \\
6. B. pettiboneae & 0.115 & 0.171 & 0.157 & 0.168 & 0.175 & - & $\underline{0.081}$ \\
7. B. longqiensis & 0.127 & 0.169 & 0.150 & 0.167 & 0.200 & $\underline{0.069}$ & - \\
\hline
\end{tabular}

Supporting the phylogenetic analyses of the COI data and concatenated COI, 16S, and ITS data, the COI distances between Branchipolynoe halliseyae n. sp. and B. kajsae n. sp. showed a clear 'barcode' gap of several percent (Figure $2 b$ ). Furthermore, a median-joining haplotype network for all COI sequences for these two species showed a minimum of 18 base changes between them (Figure 2c). The COI distances between B. seepensis and B. kajsae n. sp. and B. halliseyae n. sp. were $7.2 \%$ and $8 \%$, respectively (Table 2). For the new West Pacific species B. tjiasmantoi n. sp., there was a COI distance of at least $13.6 \%$ to each of the four new Costa Rican species, as well as to B. seepensis and B. symmytilida. It was approximately $9 \%$ to $10 \%$ divergent from the Japanese B. pettiboneae and also the Indian Ocean B. longqiensis (Table 2). Five COI sequences available on GenBank, MK694794-799, and identified in [46] as B. pettiboneae from vents in the Manus Basin (Papua New Guinea), all fell within the clade identified here as Branchipolynoe tjiasmantoi $\mathrm{n}$. sp. They were all at least $9 \%$ divergent from other GenBank B. pettiboneae sequences. One of the sequences, MK694796, was the same haplotype as specimens from sites further east (Figure 5e), while the others were more divergent (up to $3.2 \%$ ) from other Branchipolynoe tjiasmantoi $\mathrm{n}$. sp. haplotypes (Table 2) but were regarded here as the same species.

The Costa Rican samples fell into two areas of the COI tree (Figure 1): Branchipolynoe halliseyae $\mathrm{n}$. sp. and B. kajsae n. sp. formed a clade (weakly supported) that was a well-supported sister group to the Gulf of Mexico B. seepensis, while B. eliseae n. sp. and B. meridae n. sp. formed a clade (weakly supported) that was sister group to the EPR B. symmytilida. The West Pacific and Indian Ocean species, including the new species $B$. tjiasmantoi $\mathrm{n}$. sp., formed a well-supported clade that was a sister group to the B. halliseyae n. sp. + B. kajsae n. sp. + B. seepensis clade (Figure 1). The ML phylogeny (likelihood score of -8344.808 ), based on the combined COI, 16S, and ITS data for an individual from each species, showed (Figure 3) largely the same topology as the COI data alone (Figure 1). The only difference was that B. eliseae $\mathrm{n}$. sp. was a sister group to B. symmytilida, though this was poorly supported, and the MP analysis of this concatenated dataset (not shown) showed the same topology as Figure 1, with 
B. eliseae n. sp. and B. meridae n. sp. as a clade. There was a single most parsimonious tree, with a length of 1103 steps. The ML, BI, and MP support values were high (Figure 3), with the exception of the ML and BI support of $64 \%$ and 0.6 posterior probability, respectively, for the clade of B. eliseae $n$. sp. and B. symmytilida. Also, the sister group relationship between B. pettiboneae and B. longqiensis $(77 / .99 / 65)$ was not highly supported.

a.

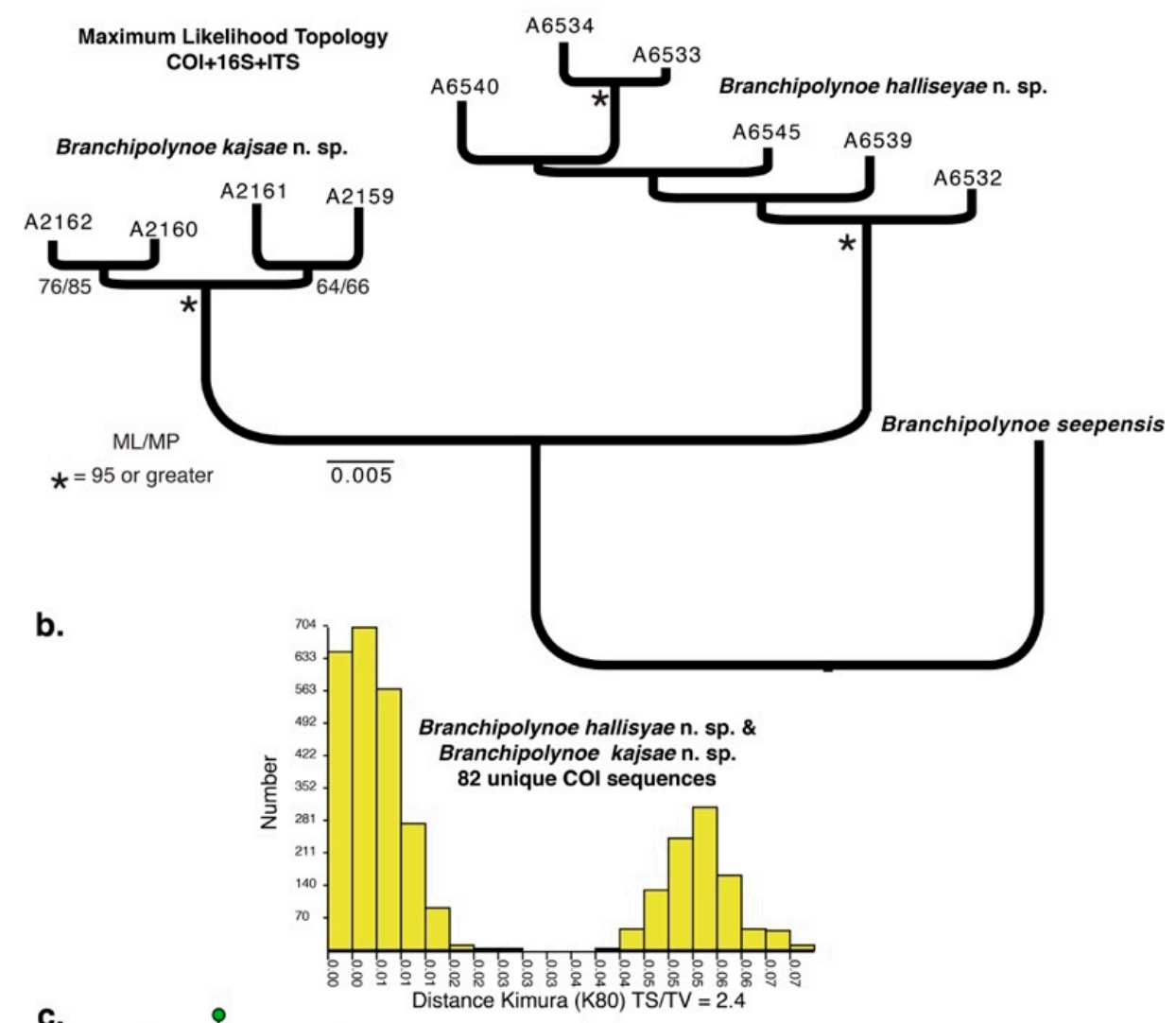

C.

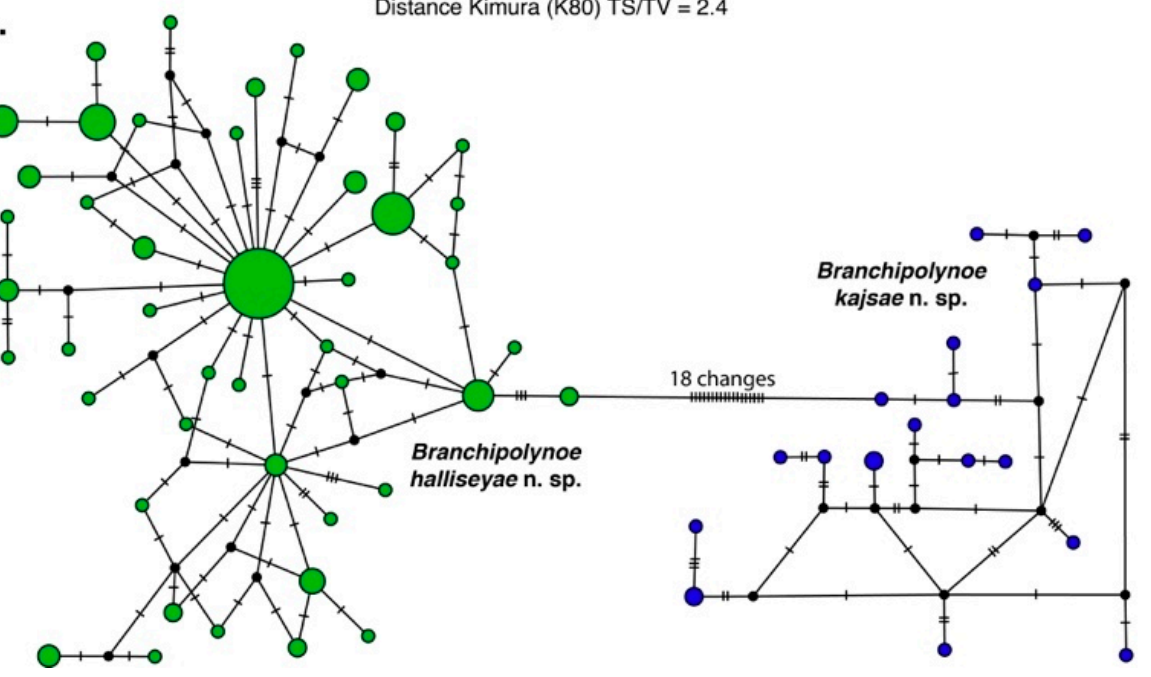

Figure 2. (a) Maximum likelihood (ML) tree from combined COI, 16S, and ITS for a subset of Branchipolynoe halliseyae n. sp. and B. kajsae n. sp. specimens, rooted with B. seepensis. (b) Automated barcode gap definition (ABGD) plot [54] of pairwise distances for 82 unique COI sequences for B. halliseyae n. sp. and B. kajsae n. sp. to assess species delineation. (c) Median-joining haplotype network for all 144 COI sequences for B. halliseyae n. sp. and B. kajsae n. sp. 


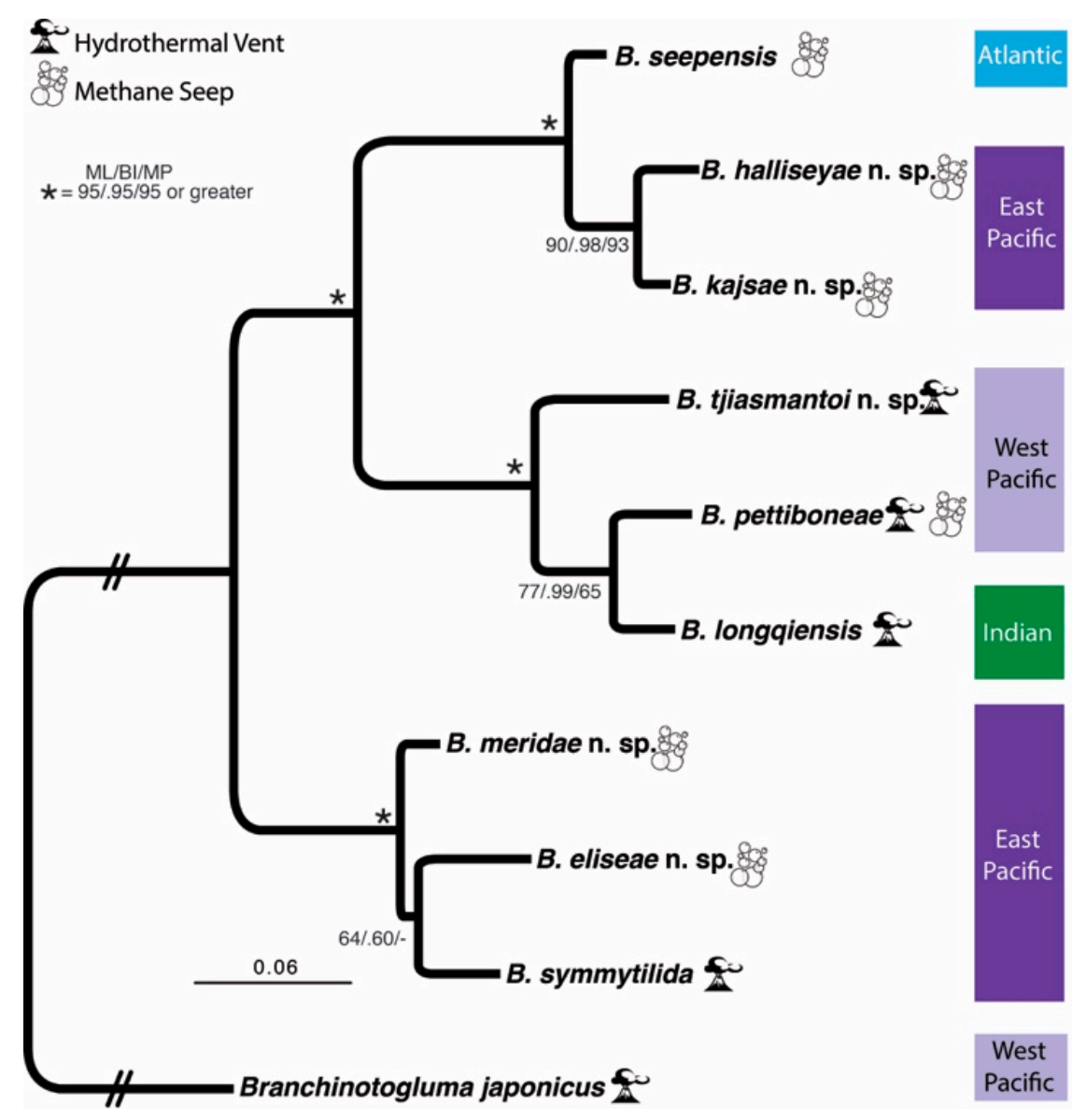

Figure 3. Maximum likelihood (ML) and Bayesian inference tree from the analysis of the combined sequences from COI, 16S, and ITS. The topology for the single maximum parsimony (MP) tree differed in showing Branchipolynoe eliseae n. sp. as sister to B. meridae n. sp. Numbers on relevant nodes are ML bootstrap BI posterior probability and MP jackknife below. * indicates $95 \%$ bootstrap/jackknife or greater and 0.95 posterior probability or greater; ' - ' indicates the node was not found.

\subsection{Haplotype Networks, Connectivity Across Hosts and Depths}

Many individuals of each species sequenced for this study had unique COI haplotypes. Branchipolynoe eliseae n. sp. (Figure 4a,b) and B. meridae n. sp. (Figure 5c,d) each had several individuals with unique haplotypes, and only one or two were shared. Branchipolynoe kajsae n. sp. had up to 17 haplotypes for 19 individuals (Figure 5a,b), while B. halliseyae n. sp. had 51 haplotypes for the 125 individuals sequenced (Figure 4c,d). Branchipolynoe tjiasmantoi n. sp. showed 20 haplotypes for the 37 individuals sequenced (Figure 5e). The Costa Rican species did not show any obvious association among similar haplotypes to depth or host mussel. Some of the same haplotypes were found in all three hosts and across all depths and localities. All four new Costa Rican Branchipolynoe species were found in the host mussel Bathymodiolus sp. 1. All except B. meridae n. sp. were also found in host Bathymodiolus sp. 2, and all except B. eliseae n. sp. were found in host Bathymodiolus sp. 3 (Table 1, Figures $4 \mathrm{~b}, \mathrm{~d}$ and $5 \mathrm{~b}, \mathrm{~d})$. All four new species were found from 1000 to $1800 \mathrm{~m}$, with haplotypes shared across that depth span for B. eliseae n. sp., B. halliseyae n. sp., and B. meridae n. sp. For the species where reasonable numbers of individuals were sampled, B. halliseyae n. sp. and B. kajsae n. sp., $\phi_{\mathrm{ST}}$ values were near 0 when assessed using either host or depth, with no significant differences. For $B$. tjiasmantoi n. sp. (Figure 5e), 18 of the 43 specimens were sequenced from Vanuatu, and 18 of the 23 haplotypes were represented by singletons. Three specimens sequenced from Tonga showed differing haplotypes that were shared with specimens from Fiji, Kermadec, and Vanuatu. Six specimens from Vanuatu shared the same haplotype with three specimens from Fiji and one from Tonga (Figure 5e). 
The distance between Vanuatu and Tonga is over $1500 \mathrm{~km}$. One haplotype was shared between Fiji, Manus, Tonga, and Vanuatu, a maximum distance of well over $4000 \mathrm{~km}$. Other haplotypes were shared between Vanuatu and Kermadec and Tonga and Kermadec, representing distances of over $2000 \mathrm{~km}$. $\phi_{\mathrm{ST}}$ values were near 0 , with no significant difference between localities.

a

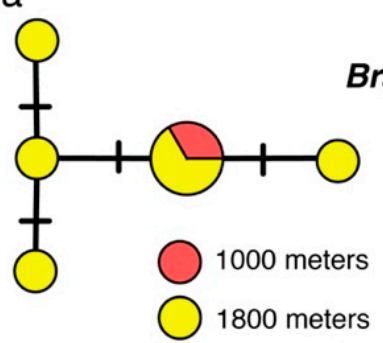

b

Branchipolynoe eliseae n.sp.

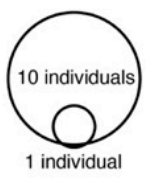

7 individuals

Bathymodiolus sp. 1

Bathymodiolus sp. 2

unknown

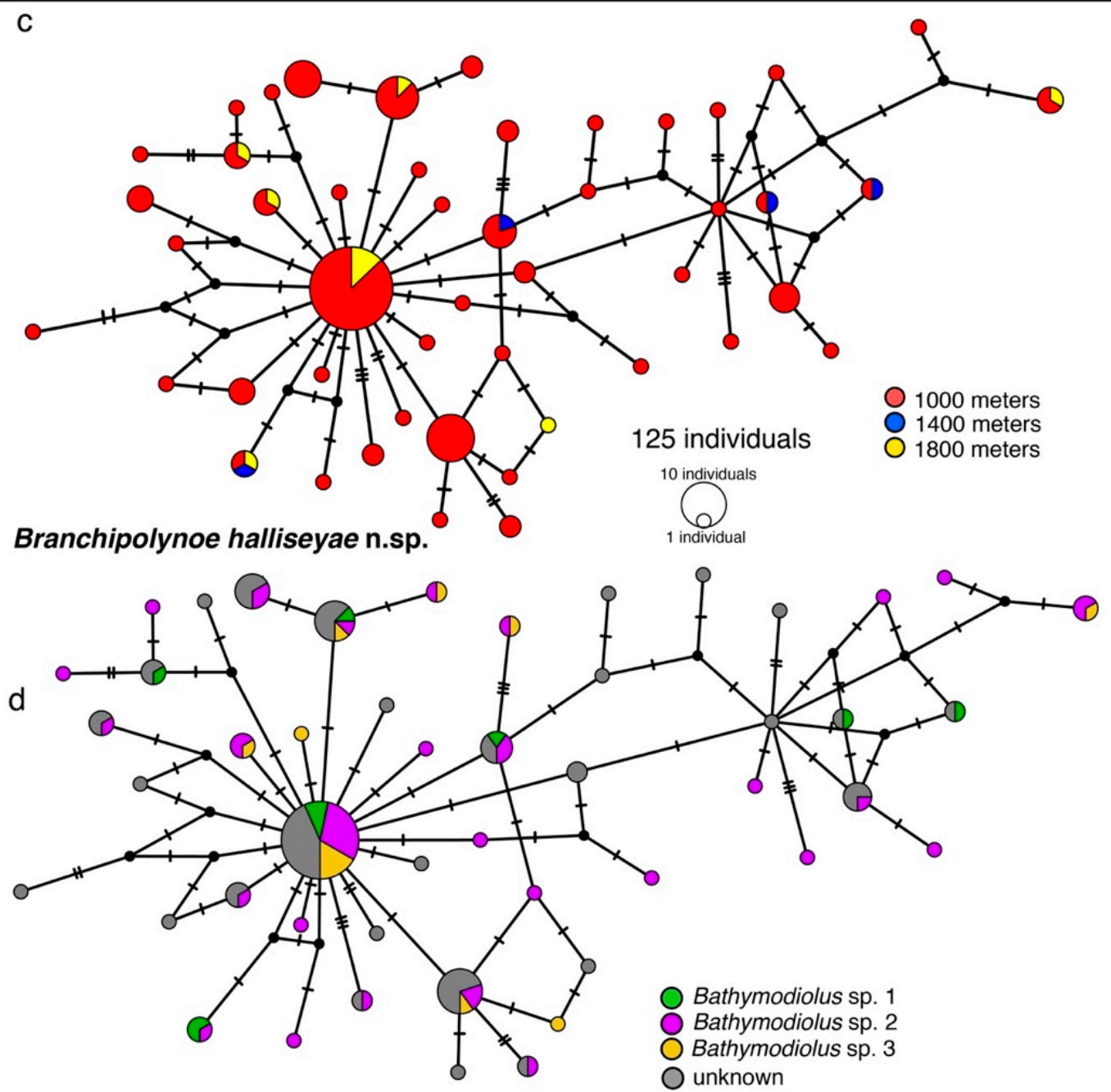

Figure 4. (a) COI haplotype network for 7 individuals of Branchipolynoe eliseae n. sp. with depth coding. (b) COI haplotype network for 7 individuals of Branchipolynoe eliseae $\mathrm{n}$. sp. with host coding (where known). (c) COI haplotype network for 125 individuals of Branchipolynoe halliseyae n. sp. with depth coding. (d) COI haplotype network for 125 individuals of Branchipolynoe halliseyae $\mathrm{n}$. sp. with host coding. Many hosts were unknown owing to the worms being found outside the shells. 

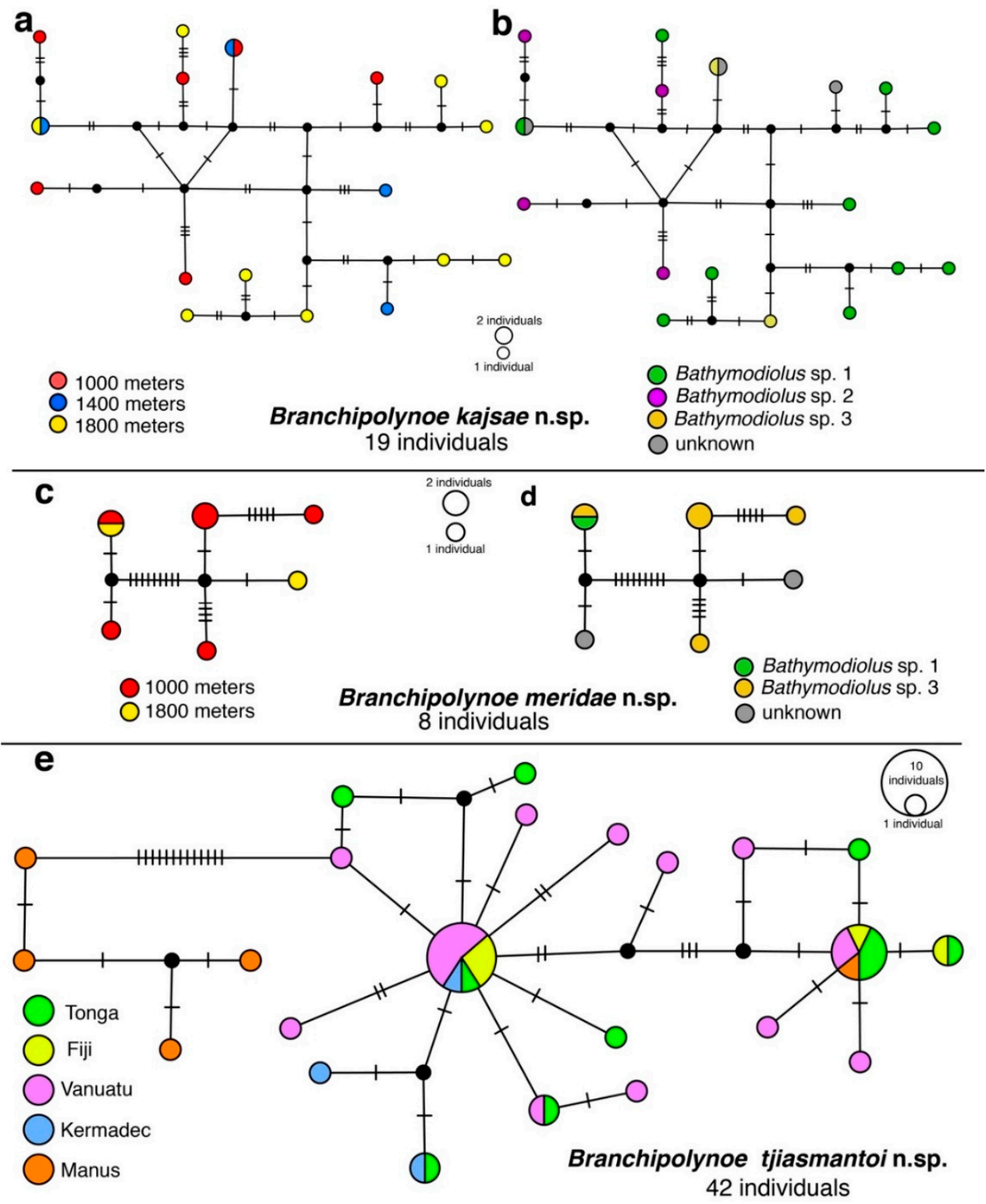

Figure 5. (a) COI haplotype network for 19 individuals of Branchipolynoe kajsae n. sp. with depth coding. (b) COI haplotype network for 19 individuals of Branchipolynoe kajsae n. sp. with host coding (where known). (c) COI haplotype network for 8 individuals of Branchipolynoe meridae n. sp. with depth coding. (d) COI haplotype network for 8 individuals of Branchipolynoe meridae $\mathrm{n}$. sp. with host coding (where known). (e) COI haplotype network for 42 individuals of Branchipolynoe tjiasmantoi $\mathrm{n}$. sp. with colors indicating geographic locality.

\subsection{Character Transformations}

The ancestral habitat for Branchipolynoe was inferred to be seeps, though only with a likelihood of $62 \%$ (Figure 6a). If this is accepted as the ancestral habitat, then there have been two transitions to vents, one for the eastern Pacific B. symmytilida and one for the West Pacific and Indian Ocean species, including B. tjiasmantoi $\mathrm{n}$. sp. Branchipolynoe pettiboneae, which is part of this clade and the only West Pacific Branchipolynoe species to occur at seeps, likely had a vent ancestor and has secondarily colonized seeps. The ancestral locality for Branchipolynoe is uncertain, with the highest likelihood (only $48 \%$ ) being assigned to the Eastern Pacific (Figure 6b). 


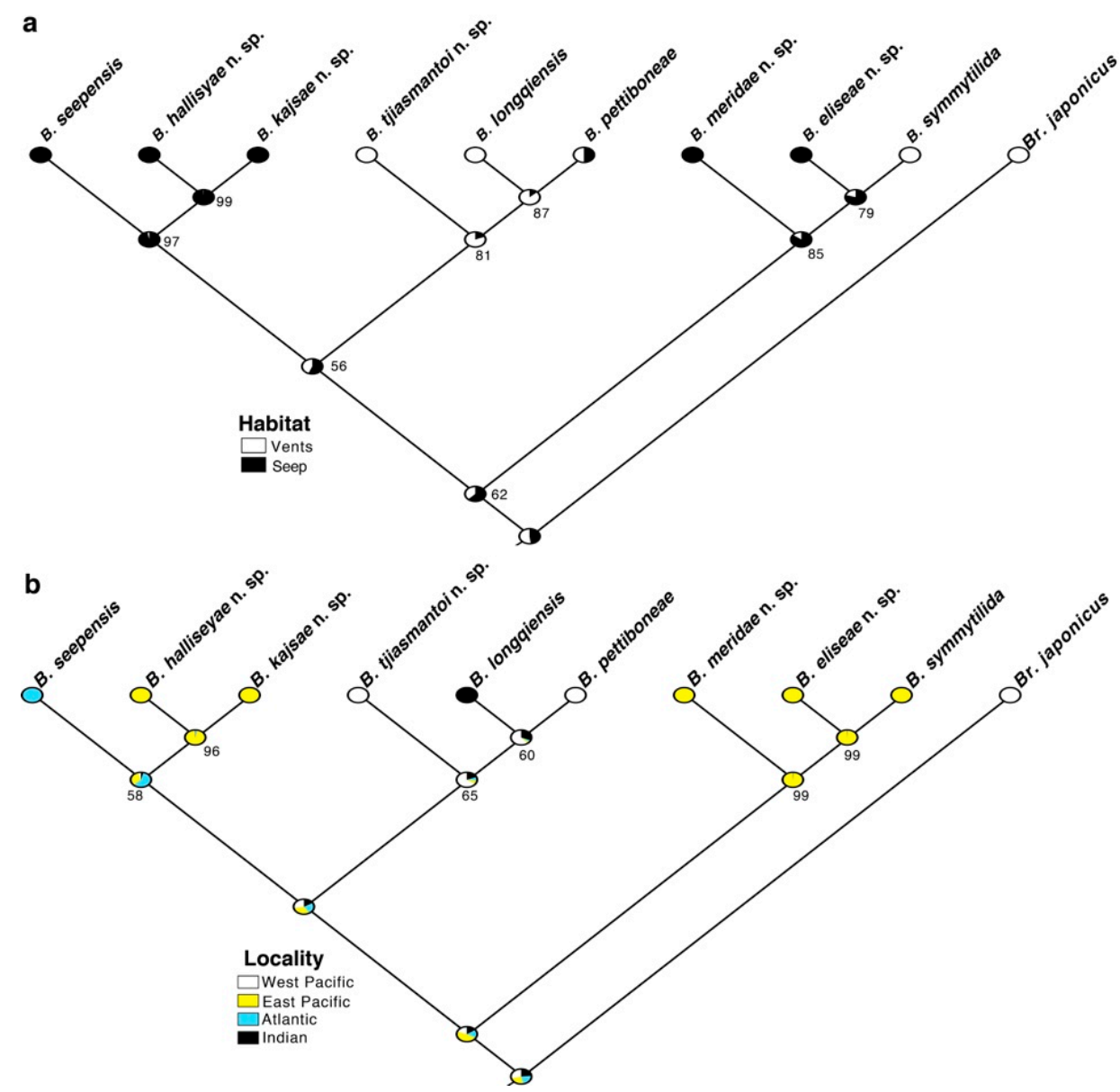

Figure 6. Maximum likelihood tree topology from concatenated data (COI, 16S, and ITS) with the transformation for (a) habitat: vent or seep and (b) geographic locality, under the MK1 model. 'Pie charts' at the nodes represent probabilities for the relevant states. Where one state was above $50 \%$ likelihood, the number is written at the node.

\section{Discussion}

The discovery of five new species from Pacific Costa Rican seeps and West Pacific vents more than doubles the number of named Branchipolynoe species. These species are genetically distinct, and most show clear morphological differences, though B. halliseyae n. sp. and B. kajsae n. sp. show no obvious morphological differences and have low molecular divergence. The fact that four of the species are sympatric is surprising given previous studies on Branchipolynoe. There have only been four previously described species from hydrothermal vents and methane seeps across the world [7,19-21], though evidence for undescribed species has been presented [23]. The Costa Rican assemblage of four sympatric clades arguably represents a cryptic species complex, which are morphologically similar, yet genetically distinct [58]. Cryptic species of animals have been found repeatedly from hydrothermal vents and methane seeps [59-62]. Describing animal species with few obvious morphological differences is becoming more routine based on molecular data [63]. Doing so may separate previously believed cosmopolitan species [61,62], which is important for understanding biogeographical patterns, species distributions, and depth and habitat preferences [64].

There is no consensus on a minimum COI distance required to delimitate species, and this varies markedly across taxa [65]. However, substantially larger minimum interspecific distances over maximum intraspecific distances often support the recognition of new species [66,67]. The four sympatric Costa Rica Branchipolynoe nominal species were recovered as sibling species pairs on the COI phylogeny (Figure 1): B. kajsae n. sp. with B. halliseyae n. sp. and B. meridae n. sp. with B. eliseae n. 
sp. Examination of the minimum COI distances (Table 2) showed B. kajsae n. sp. and B. halliseyae n. sp. as $3.7 \%$ divergent ( $4.5 \%$ model-corrected) and B. meridae $\mathrm{n}$. sp. and B. eliseae $\mathrm{n}$. $\mathrm{sp}$. as $6.5 \%$ divergent (8.5\% model-corrected). The COI divergence between B. meridae $\mathrm{n}$. sp. and B. eliseae $\mathrm{n}$. sp. and the multigene phylogeny (Figure 3 ) showing that B. eliseae n. sp. is actually more closely related to the hydrothermal vent $B$. symmytilida make a compelling case that these are indeed separate taxa. This is also supported by the presence of much smaller elytra in B. meridae n. sp. compared to B. eliseae n. sp. (see Section 5. Taxonomy).

The situation is not so clear cut for the Branchipolynoe kajsae n. sp. and B. halliseyae n. sp. species pair. The COI divergence is relatively low, and they are sister taxa on the multigene phylogeny (Figure 2). However, as explored in Figures 1-3, there is a distinct gap in terms of intraclade versus interclade divergences for the two nominal species (Figure 2b). This is made very clear in the haplotype network that includes both species (Figure 2c). This break occurs with the COI data for numerous individuals and for multigene data with more restricted sampling (Figure 2a). Nuclear ITS data has been shown to be useful as a marker for the separation of cryptic species $[64,68]$. While Branchipolynoe kajsae n. sp. and B. halliseyae n. sp. have a relatively small minimum-corrected COI distance of $3.7 \%$, the minimum-corrected ITS distance between them was $2.6 \%$, which was greater than that found between other Branchipolynoe species, such as B. symmytilida and B. meridae n. sp. (1.6\%) (Table 3). The circumstances under which B. halliseyae n. sp. and B. kajsae n. sp. diverged from each other is unclear, as they currently share the same habitat, host mussels, and depths (Figures 4 and 5). Nevertheless, we recognize B. kajsae n. sp. and B. halliseyae n. sp. as distinct species taxa here. This is also supported by the fact that a clear difference was found in the parapodia. In B. halliseyae n. sp., the notoacicular lobe reaches the tips on the notochaetae, while in B. kajsae n. sp. it only reached half of length of notochaetae.

The four new Costa Rican species are the only known sympatric Branchipolynoe species to date. However, despite sharing the same locality, they show distinct evolutionary histories. Branchipolynoe halliseyae n. sp. and B. kajsae n. sp. formed a clade with B. seepensis that was the well-supported sister group to the West Pacific/Indian Ocean clade of Branchipolynoe (Figures 1 and 2). As B. halliseyae $\mathrm{n}$. sp. and B. kajsae n. sp. were most closely related to B. seepensis, which is found in the Gulf of Mexico, they likely diverged from $B$. seepensis by a vicariant event resulting from the formation of the Panama Isthmus, which began forming 23 to 25 million years ago and finally became a land barrier around 3.5 million years ago [69,70].

The two other Costa Rican species, B. meridae n. sp. and B. eliseae n. sp. formed a clade with $B$. symmytilida, which lives at hydrothermal vents on the EPR to the west, and these three taxa form the sister group to the remaining Branchipolynoe. Based on Figure 6a, the most recent common ancestor for the B. symmytilida, B. meridae n. sp., and B. eliseae n. sp. clade likely lived at methane seeps, with a recent ancestor of $B$. symmytilida, therefore having made a habitat shift to hydrothermal vents. Other studies on deep-sea annelid diversity have found biogeographical patterns similar to those seen here. For instance, a study on Amphisamytha Hessle, 1917, showed sympatric species that were not the most closely related [62] and that a species occurring at Costa Rican methane seeps, A. fauchaldi Solís-Weiss \& Hernández-Alcántara, 1994, had a sister group at hydrothermal vents of the Mid-Atlantic Ridge, rather than to other Pacific Amphisamytha. In contrast, a study on Archinome Kudenov, 1991, found that A. levinae Borda, Kudenov, Chevaldonné, Blake, Desbruyeres, Fabri, Hourdez, Pleijel, Shank, Wilson, Schulze \& Rouse, 2013, from eastern Pacific vents and seeps, including Costa Rican seeps, either had its closest relative at the East Pacific Rise, or to the rest of the Archinome clade [61].

Branchipolynoe forms part of a clade of scale worms associated with vent and seep habitats [1-3]. The other known species (e.g., Branchinotogluma) seem to be free-living and not obviously symbionts $[23,25,28]$. Our results suggest that Branchipolynoe may have its most recent common ancestor in the East Pacific, at a seep habitat (Figure 6). The results suggest that Branchipolynoe moved west to colonize vents and seeps in the West Pacific and Indian Ocean, as well as east to colonize seeps in the Gulf of Mexico. The most closely related Branchipolynoe species are not found in the most closely related Bathymodiolus species. The host mussels of the four new Branchipolynoe species (Bathymodiolus sp. 
1-3) are closely related to each other and to the hosts of B. symmytilida (B. thermophilus and B. antarcticus) from the East Pacific Rise, forming a single clade (McCowin et al. in prep.).

For the new Costa Rican species, there was no obvious relationship between haplotypes and host mussel or depth (Figures 4-6). There were also no marked genetic distances between individuals of the same species living in different depths or hosts. Some of the same haplotypes were found at different depths and different hosts (Figures 4-6). This suggests that Branchipolynoe species at Costa Rican methane seeps have no preference for host mussel species and disperse between 1000 and $1800 \mathrm{~m}$ with little difficulty. However, two species were found mostly at $1000 \mathrm{~m}$ (B. halliseyae $\mathrm{n}$. sp. and B. meridae n. sp.), and the other species were mostly found at $1800 \mathrm{~m}$ (B. kajsae n. sp. and B. eliseae n. sp.) (Table 1), though this may simply be a sampling artefact. The haplotype networks for the sister species B. halliseyae n. sp. and B. kajsae n. sp. showed different patterns. The B. halliseyae n. sp. network has an overall star shape (Figure $4 \mathrm{c}, \mathrm{d}$ ) suggestive of a bottleneck in the past. On the contrary, for B. kajsae n. sp. there is a balanced network (Figure 5a,b), with similar frequencies of each haplotype, which suggests that the species did not experience a recent bottleneck. There was also no correlation between similar haplotypes of B. tjiasmantoi n. sp. and locality (Figure 5e). Shared haplotypes were found across several distant localities, including Tonga and Manus, separated by over $4000 \mathrm{~km}$. This suggests that $B$. tjiasmantoi $\mathrm{n}$. sp. larvae can either disperse long distances between vents and/or there are numerous vent systems allowing for gene flow. There are undoubtedly more Branchipolynoe species to be discovered at hydrothermal vents and methane seeps across the world. Further research into these vent and seep communities may provide valuable insight into the dispersal and adaptation of these fascinating worms.

\section{Taxonomy}

\section{Polynoidae Kinberg, 1856}

Branchipolynoinae Pettibone, 1984

Branchipolynoe Pettibone, 1984

\section{Type species: Branchipolynoe symmytilida Pettibone, 1984}

Diagnosis (emended)—Polynoidae with branchiae, small or well developed, but always arborescent, starting on Segments 2 or 3. Prostomium bilobed with median antenna and lacking lateral antennae; eyes absent. Prostomial lobes with or without minute frontal filaments. First segment achaetous and fused to the prostomium with two pairs of anterior cirri (= tentacular cirri). Five pairs of terminal papillae on proboscis, dorsal and ventral to mouth; two pairs of jaws. Elytra small, not covering dorsum, to nearly absent; on Segments 2, 4, 5, 7, 9, 11, 13, 15, 17, and 19. Parapodia biramous to subbiramous; notopodia small with few notochaetae; neurochaetae often divided in two groups: supra-acicular (stout or slender) and subacicular (stout or slender). Females with elongated ventral papillae on Segments 11 and 12. Males, where known, smaller than adult females and with paired elongated ventral papillae on Segment 12. Commensal with bathymodiolin mussels at methane seeps or hydrothermal vents.

Remarks-Branchipolynoe was erected and diagnosed for Branchipolynoe symmytilida by Pettibone [7], and later emended by Pettibone [19] to include B. seepensis. Miura \& Hashimoto [20] and Zhou et al. [21] did not alter the diagnosis when describing B. pettiboneae and B. longqiensis, respectively. Zhou et al. [21] did present a table comparing the different Branchipolynoe species, and we have updated that here (Table 4). Elytral size, which is notably small in Branchipolynoe, had not previously been part of the generic diagnosis for Branchipolynoe. Also, the presence of elongated ventral papillae on Segments 11 and 12 is added here, as well as the fact that this is for females, while males (where known) have a single pair on Segment 12 in the present study [16,17]. Pettibone [7] noted a pair of 'frontal filaments' on the prostomium of B. symmytilida, and no other Branchipolynoe species has such frontal filaments. These may turn out to be reduced lateral antennae, but further study is needed. We use the term anterior cirri here to refer to cirri on Segment 1, following Rouse \& Pleijel [71] (p. 21) who use this term instead of tentacular cirri, in order make it clear that these are segmental structures. 
Table 4. Characters of the nine Branchipolynoe species.

\begin{tabular}{|c|c|c|c|c|c|c|c|c|c|}
\hline Characters & B. symmytilida & B. seepensis & B. pettiboneae & B. longqiensis & $\begin{array}{l}\text { B. eliseae } \mathrm{n} . \\
\mathrm{sp.}\end{array}$ & $\begin{array}{c}\text { B. halliseyae } \mathrm{n} . \\
\text { sp. }\end{array}$ & $\begin{array}{l}\text { B. kajsae n. } \\
\text { sp. }\end{array}$ & $\begin{array}{l}\text { B. meridae } \mathrm{n} . \\
\mathrm{sp} .\end{array}$ & $\begin{array}{l}\text { B. tjiasmantoi n. } \\
\text { sp. }\end{array}$ \\
\hline Elytra & $\begin{array}{c}\text { Partially covering } \\
\text { parapodia }\end{array}$ & $\begin{array}{l}\text { Covering } \\
\text { parapodia, } \\
\text { dorsum } \\
\text { exposed }\end{array}$ & $\begin{array}{c}\text { Covering } \\
\text { parapodia, } \\
\text { dorsum exposed }\end{array}$ & $\begin{array}{l}\text { Covering } \\
\text { parapodia, } \\
\text { dorsum } \\
\text { exposed }\end{array}$ & $\begin{array}{c}\text { Partially } \\
\text { covering } \\
\text { parapodia }\end{array}$ & $\begin{array}{l}\text { Fully or partially } \\
\text { covering } \\
\text { parapodia }\end{array}$ & $\begin{array}{l}\text { Fully or } \\
\text { partially } \\
\text { covering } \\
\text { parapodia }\end{array}$ & $\begin{array}{l}\text { Minute, most } \\
\text { of parapodia } \\
\text { exposed }\end{array}$ & $\begin{array}{c}\text { Covering } \\
\text { parapodia, } \\
\text { dorsum exposed }\end{array}$ \\
\hline $\begin{array}{c}\text { Frontal } \\
\text { filaments }\end{array}$ & Minute & Absent & Absent & Absent & Absent & Absent & Absent & Absent & Absent \\
\hline $\begin{array}{c}\text { First } \\
\text { branchiae }\end{array}$ & Segment 2 & Segment 3 & Segment 3 & Segment 3 & Segment 2 & Segment 2 & Segment 2 & Segment 2 & Segment 3 \\
\hline Branchiae & Long & Short, dense & Short, dense & Short, dense & Long & Short, dense & Short, dense & Long & Short, dense \\
\hline Dorsal cirri & Short & Short & Short & Short & Short & Long & Long & Short & Short \\
\hline Parapodium & Subbiramous & Biramous & Subbiramous & Subbiramous & Subbiramous & Biramous & Biramous & Subbiramous & Subbiramous \\
\hline $\begin{array}{l}\text { Notopodial } \\
\text { acicular lobe }\end{array}$ & $\begin{array}{c}\text { Rounded, very } \\
\text { short }\end{array}$ & $\begin{array}{l}\text { Triangular, } \frac{1}{2} \\
\text { notochaetal } \\
\text { length }\end{array}$ & $\begin{array}{c}\text { Digitiform, very } \\
\text { short }\end{array}$ & $\begin{array}{c}\text { Straight, } \\
\text { reaching tip of } \\
\text { notochaetae }\end{array}$ & $\begin{array}{l}\text { Digitiform, } \frac{1}{2} \\
\text { notochaetal } \\
\text { length }\end{array}$ & $\begin{array}{l}\text { Straight, reaching } \\
\text { tip of notochaetae }\end{array}$ & $\begin{array}{l}\text { Straight, } \frac{1}{2} \\
\text { notochaetal } \\
\text { length }\end{array}$ & $\begin{array}{l}\text { Rounded, } \\
\text { very short }\end{array}$ & $\begin{array}{l}\text { Digitiform, longer } \\
\text { than notochaetae }\end{array}$ \\
\hline Notochaetae & Few, very short & Several, long & Few, very short & $\begin{array}{c}\text { Few, very } \\
\text { short }\end{array}$ & $\begin{array}{c}\text { Few, very } \\
\text { short }\end{array}$ & Several, long & Several, long & $\begin{array}{c}\text { Few, very } \\
\text { short }\end{array}$ & Few, very short \\
\hline $\begin{array}{l}\text { Supra-acicular } \\
\text { neurochaetae }\end{array}$ & Slightly hooked & $\begin{array}{c}\text { Tapered, blunt } \\
\text { tip }\end{array}$ & $\begin{array}{c}\text { Slender, slightly } \\
\text { hooked }\end{array}$ & $\begin{array}{l}\text { Stout, slightly } \\
\text { hooked }\end{array}$ & $\begin{array}{l}\text { Slender, } \\
\text { tapered into } \\
\text { rounded tip }\end{array}$ & $\begin{array}{l}\text { Slender, tapered } \\
\text { tip, subdistal } \\
\text { swelling }\end{array}$ & $\begin{array}{c}\text { Slender, } \\
\text { tapered tip, } \\
\text { subdistal } \\
\text { swelling }\end{array}$ & $\begin{array}{l}\text { Stout, straight, } \\
\text { subdistal } \\
\text { swelling }\end{array}$ & $\begin{array}{l}\text { Slender, rounded } \\
\text { tip, subdistal } \\
\text { swelling }\end{array}$ \\
\hline $\begin{array}{l}\text { Subacicular } \\
\text { neurochaetae }\end{array}$ & $\begin{array}{c}\text { Slender, slightly } \\
\text { hooked }\end{array}$ & $\begin{array}{l}\text { Slender, } \\
\text { slightly } \\
\text { hooked }\end{array}$ & Slightly hooked & $\begin{array}{l}\text { Slender or } \\
\text { stout, slightly } \\
\text { hooked }\end{array}$ & $\begin{array}{l}\text { Similar to } \\
\text { supra-acicular, } \\
\text { slightly } \\
\text { hooked }\end{array}$ & $\begin{array}{c}\text { Similar to } \\
\text { supra-acicular, } \\
\text { shorter subdistal } \\
\text { area }\end{array}$ & $\begin{array}{l}\text { Similar to } \\
\text { supra-acicular, } \\
\text { shorter } \\
\text { subdistal area }\end{array}$ & $\begin{array}{l}\text { Slender, } \\
\text { rounded tip, } \\
\text { longer } \\
\text { subdistal area }\end{array}$ & $\begin{array}{l}\text { Stout, shorter } \\
\text { subdistal area }\end{array}$ \\
\hline Habitat & Vents & Seeps & Vents \& Seeps & Vents & Seeps & Seeps & Seeps & Seeps & Vents \\
\hline $\begin{array}{c}\text { Host } \\
\text { Bathymodiolus } \\
\text { mussel }\end{array}$ & $\begin{array}{l}\text { B. thermophilus \& } \\
\text { B. antarcticus }\end{array}$ & $\begin{array}{l}\text { Unknown } B \text {. } \\
\text { heckerae? }\end{array}$ & $\begin{array}{l}\text { B. brevior, B. } \\
\text { japonicas, } \mathcal{E} \\
\text { Gigantidas } \\
\text { platifrons }\end{array}$ & B. marisindicus & $\begin{array}{c}\text { B.n. sp. } 1 \text { and } \\
2\end{array}$ & B. n. sp. $1-3$ & B. n. sp. 1-3 & B.n. sp. 1 and & $\begin{array}{l}\text { Bathymodiolus spp. } \\
\text { including } B . \\
\text { brevior }\end{array}$ \\
\hline
\end{tabular}




\section{Branchipolynoe eliseae, new species Figures 7 and 8}

Materia-Costa Rica, Eastern Pacific, from dives of HOV Alvin in 2010 and 2017, associated with Bathymodiolus mussels at methane seeps. Holotype (SIO-BIC A6660): Mound 12, 8.93 ${ }^{\circ} \mathrm{N}, 84.31^{\circ} \mathrm{W}$, 1009 m, Alvin Dive 4922, 5 June 2017, collectors J. Le \& C. Roman. Paratype (MZUCR 403-01): Jaco Scar, $9.12^{\circ} \mathrm{N}, 84.84^{\circ} \mathrm{W}, 1802 \mathrm{~m}$, Alvin Dive 4591, 12 January 2010, collector G. Rouse, 1 specimen. Paratypes (SIO-BIC A6548-A6552): Jaco Scarp, 9.12 ${ }^{\circ}$ N, 84.84 ${ }^{\circ}$ W, 1800 m, Alvin Dive 4590, 11 January 2010, collector G. Rouse, 5 specimens.

Etymology-Named in honor of Elise Lindgren, sister of the first author.

Host-Bathymodiolus n. sp. 1 and 2 (McCowin et al. in prep.).

Description-Body long, tapered anteriorly and posteriorly. Adults with 21 Segments, including first achaetous segment (Figure 7a,b). Prostomium nearly unilobed with barely discernible rounded anterior lobes, very short conical median antenna directly inserted in a shallow anterior notch, and pair of short conical palps (Figure 7a,b). Median antenna and palps all smooth and much shorter than prostomium length. Prostomium without frontal filaments, lateral antennae, and eyes. Five pairs of terminal papillae surrounding the mouth opening; two pairs of jaws lined with small teeth (Figure 8e). First segment achaetous, fused to prostomium with two pairs of short anterior cirri. Length of anterior cirri not exceeding length of prostomium. All cirri, antenna and palps smooth. Ten pairs of elytra, attached to elytrophores on Segments 2, 4, 5, 7, 9, 11, 13, 15, 17, and 19 respectively (Figure 7a). Elytra small, ellipsoidal, smooth, without border papillae, only covering part of parapodium and leaving most of dorsum uncovered, largest on Segments 9 and 11 (Figures 7a and 8a). Non-elytrigerous Segments with short, stout and smooth dorsal cirri, longer than anterior and ventral cirri, on cylindrical cirrophores. Dorsal cirri tapering gradually and not extending beyond tip of neurochaetae. Branchiae arborescent with long terminal filaments (Figures $7 \mathrm{a}$ and $8 \mathrm{~b}-\mathrm{d}$ ), emerging in one large (in volume) dorsal group and one smaller, more ventral, group (Figure $8 \mathrm{~b}-\mathrm{d}$ ). Branchiae on all Segments from Segment 2. No discernible dorsal tubercles. Parapodia subbiramous with minute notopodia; short, distally truncated notochaetae only reaching base of neurochaetae (Figure 8c,e,f). Notopodial acicular lobe digitiform, about half length of notochaetae, slightly curved downward. Neuropodia deeply cleft, with rounded lobes and no protruding aciculum. Notochaetae stouter and shorter (Figure 8c,f) than neurochaetae (Figure 8c,g,h). Tip rounded, shaft with inconspicuous rows of spines. Neurochaetae numerous, arranged as a vertical fan. Neurochaetae all similar in general appearance with a subdistal swelling with two rows of small spines on the edge and tapering into a rounded tip. Subacicular neurochaetae slightly hooked, supra-acicular neurochaetae with a longer subdistal part and straight (Figure 8c,g,h). Ventral cirri small, smooth, without papillae, same length as anterior cirri, and attached to middle of neuropodia (Figure $7 \mathrm{~b}, \mathrm{~d}$ ). Ventral cirri on Segment 2 clearly longer than following ones, and projecting anteriorly. Elongated ventral papillae on Segments 11 and 12 project posteriorly and do not extend beyond one-third of following segment (Figure $7 \mathrm{~b}$ ). Pygidium round with pair of short, conical anal cirri. Anus terminal.

Morphological variation-Holotype is $45 \mathrm{~mm}$ long, $6 \mathrm{~mm}$ wide, including parapodia. Paratypes varying in size from $8-40 \mathrm{~mm}$ long and from $3-13 \mathrm{~mm}$ wide, including juveniles. All specimens with elongated ventral papillae on Segments 11 and 12, suggesting that males were not found.

Remarks-Branchipolynoe eliseae n. sp. is closest relative to B. symmytilida (Figure 3), or possibly B. meridae n. sp. (Figure 1). Branchipolynoe eliseae n. sp. can be distinguished from B. meridae n. sp. by the size of the elytra, with the latter species having the smallest of any Branchipolynoe species, though they can be small in some B. eliseae n. sp. Branchipolynoe symmytilida has 'frontal filaments', which are not present in any other Branchipolynoe. The two other species sympatric with B. eliseae n. sp., B. halliseyae n. sp. and B. kajsae n. sp., have larger elytra and short, dense branchiae. Also B. eliseae n. sp. differs from B. meridae n. sp., B. halliseyae n. sp., and B. kajsae n. sp., in having two different neurochaetae: with straight (supra-acicular) and slightly hooked (subacicular) tips (Table 4). 

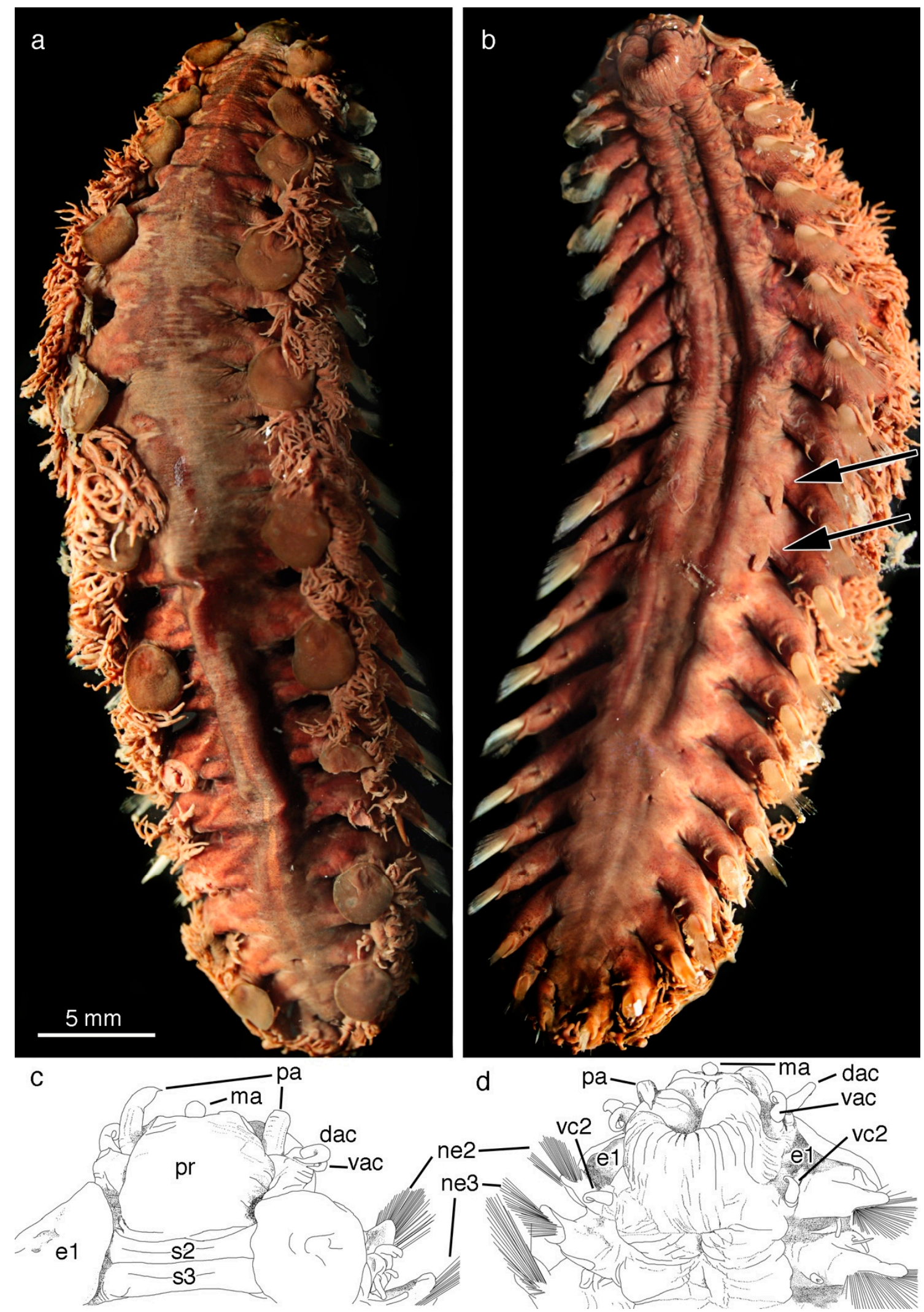

Figure 7. Branchipolynoe eliseae n. sp. female holotype (SIO-BIC A6660) (a) Dorsal view. (b) Ventral view. Arrows indicate elongated ventral papillae of Segments 11 and 12. (c) Drawing of dorsal anterior. (d) Drawing of ventral anterior. Abbreviations: pa, palps; ma, median antenna; pr, prostomium; e1, first elytron (attached on Segment 2); s2 and s3, Segments 2 and 3; dac, dorsal anterior cirrus; vac, ventral anterior cirrus; ne2 and ne3, neuropodia 2 and 3; vc2, ventral cirrus on Segment 2. 

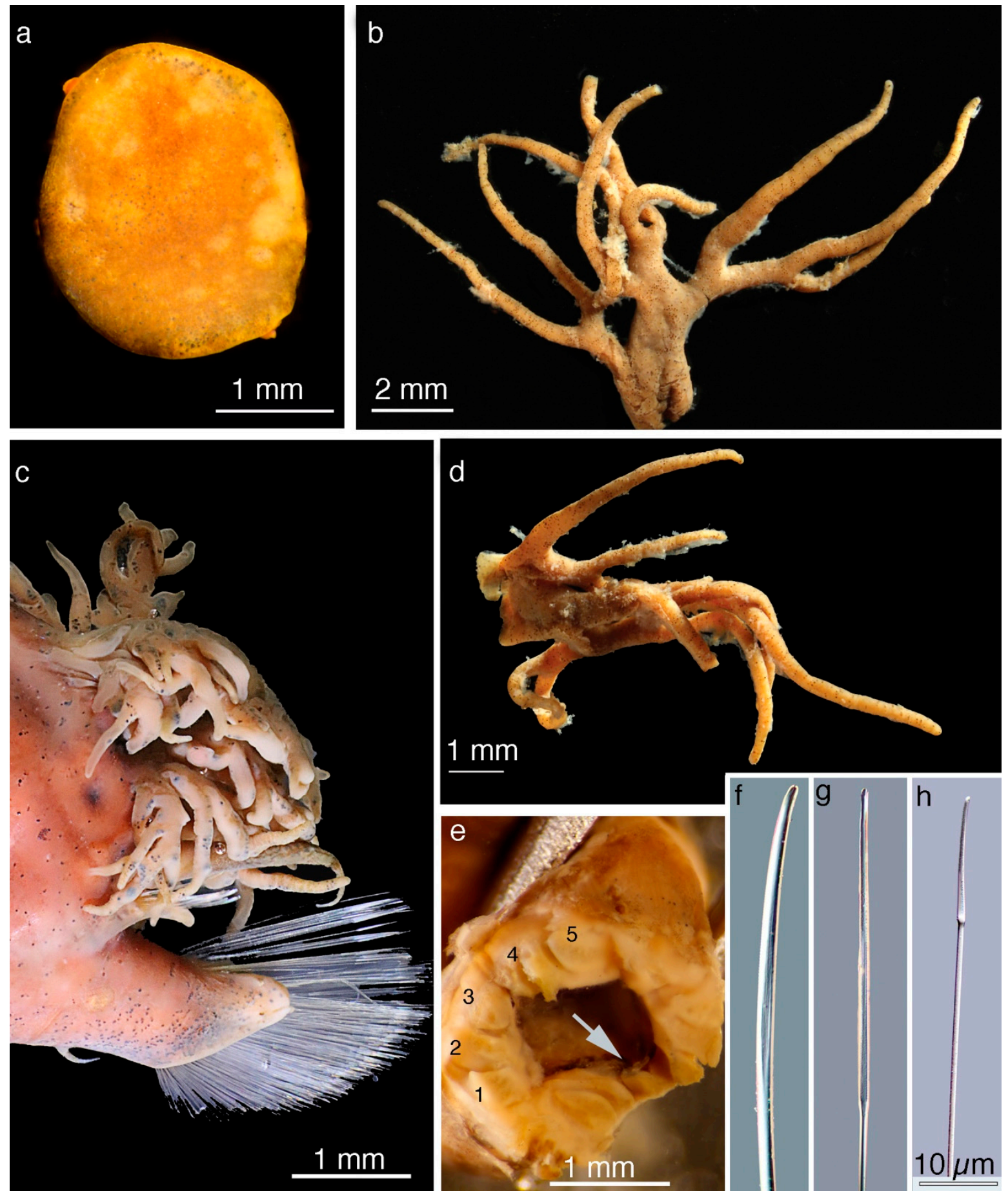

Figure 8. Branchipolynoe eliseae n. sp. paratype (MZUCR 403-01 elytron, branchiae) and holotype (SIO-BIC A6660 parapodium, chaetae): (a) Elytron from Segment 11. (b) Branchia from Segment 10 (dorsal group). (c) Parapodium from Segment 18 with dorsal cirrus. (d) Branchia from Segment 10 (ventral group). (e) Frontal view of proboscis showing papillae and jaws (arrow). (f) Notochaeta (Segment 18). (g) Supraacicular neurochaeta (Segment 18). (h) Subacicular neurochaeta (Segment 18). Same scale for $(\mathbf{f}-\mathbf{h})$.

\section{Branchipolynoe halliseyae, new species}

\section{Figures 9-11}

Material-Costa Rica, Eastern Pacific, from dives of HOV Alvin in 2009, 2010, and 2017, associated with Bathymodiolus mussels near methane seeps. Holotype female (SIO-BIC A1322): Mound 12, 8.93 
N, $84.31^{\circ}$ W, 1008 m, Alvin Dive 4501, 22 February 2009, collectors G. Rouse \& D. Huang. Paratypes females, except where indicated (SIO-BIC A6530-A6539): Mound 12, 8.93 $\mathrm{N}, 84.31^{\circ} \mathrm{W}, 1008 \mathrm{~m}$, Alvin Dive 4501, 22 February 2009, collectors G. Rouse \& D. Huang, 10 specimens. Paratype (SIO-BIC A6540): Mound 12, 8.93 ${ }^{\circ}$ N, $84.31^{\circ} \mathrm{W}, 1001 \mathrm{~m}$, Alvin Dive 4511, 5 March 2009, collectors G. Rouse \& D. Huang, 1 specimen. Paratypes (SIO-BIC A6541-A6547): Mound 12 (Yettisburgh), 8.93 N, 84.31 ${ }^{\circ} \mathrm{W}, 1000 \mathrm{~m}$, Alvin Dive 4586, 7 January 2010, collector G. Rouse, 7 specimens. Paratypes (SIO-BIC A2127, A2128, A2144): Mound 12 (Yettisburgh), 8.93 N, 84.31 W, $997 \mathrm{~m}$, Alvin Dive 4588, 9 January 2010, collector G. Rouse, 3 specimens. Paratypes (SIO-BIC A6558, A6568, A6570, A6575, A6578, A6592, A6593, A6595, A6596, MZUCR 404-01): Mound 12, 8.93 N, 84.31 W, 999 m, Alvin Dive 4907, 22 May 2017, collectors L. Levin \& C. Seid, 10 specimens. Paratypes (SIO-BIC A6582-A6588, A6603-A6610, A6612, A6641A6645; A6587 and A6645 are males): Mound 12, 8.93 N, 84.31 ${ }^{\circ} \mathrm{W}, 1000 \mathrm{~m}$, Alvin Dive 4909, 24 May 2017, collectors E. Cordes \& R. Smith, 21 specimens. Paratypes (SIO-BIC A6589, A6620-A6625, A6627-A6634, A6636, A6637, A6640, A6646-A6649): Mound 12, 8.93 N, 84.31 ${ }^{\circ}$ W, 1004 m, Alvin Dive 4910, 25 May 2017, collectors G. Rouse \& T. Litke, 22 specimens. Paratypes (SIO-BIC A6613, A6617, A6619): Jaco Scar, $9.12^{\circ} \mathrm{N}, 84.85^{\circ} \mathrm{W}, 1891 \mathrm{~m}$, Alvin Dive 4911, 26 May 2017, collectors L. Levin \& J. Le, 3 specimens. Paratype (SIO-BIC A6650): Jaco Scar, 9.12 ${ }^{\circ}$ N, 84.84 ${ }^{\circ}$ W, $1859 \mathrm{~m}$, Alvin Dive 4912, 27 May 2017, collectors V. Orphan \& K. Dawson, 1 specimen. Paratypes (SIO-BIC A6651, A6653, A6654, A6667, A6670): Jaco Scar, $9.12^{\circ}$ N, 84.84 ${ }^{\circ}$ W, 1886 m, Alvin Dive 4914, 29 May 2017, collectors C. Roman \& A. Durkin, 5 specimens. Paratype (SIO-BIC A6672): Jaco Scar, $9.12^{\circ} \mathrm{N}, 84.84^{\circ} \mathrm{W}, 1885 \mathrm{~m}$, Alvin Dive 4915, 30 May 2017, collectors S. Goffredi \& D. Forsman, 1 specimen. Paratypes (SIO-BIC A6673-A6685, A6687-A6702, A6704, A6705; A6690 is male): Mound 12, 8.93 N, 84.32 W, 1000 m, Alvin Dive 4917, 1 June 2017, collectors G. Rouse \& B. Moran, 31 specimens. Paratypes (SIO-BIC A6656-A6659, A6661): Mound 12, 8.93 ${ }^{\circ}$, 84.31 ${ }^{\circ} \mathrm{W}, 1009 \mathrm{~m}$, Alvin Dive 4922, 5 June 2017, collectors J. Le \& C. Roman, 5 specimens. Paratypes (SIO-BIC A6706, A6708, A6709, A6711): Quepos Seep, 9.03 N, 84.62 ${ }^{\circ}$ W, 1409 m, Alvin Dive 4924, 7 June 2017, collectors L. Levin \& K. Krasnosky, 4 specimens.

Etymology-Named in honor of Jessica Hallisey, in appreciation for her efforts at Sea Camp, who have supported the Scripps Oceanographic Collections Endowment in her honor.

Host-Bathymodiolus sp. 1, 2, 3 (McCowin et al. in prep.).

Description-Body long, slightly tapered anteriorly and posteriorly. Adults with 21 Segments, including the first achaetous segment (Figures $9 a-d$ and 10a,b). Prostomium bilobed with rounded anterior lobes, short (1/10 length of prostomium) conical median antenna directly inserted in a shallow anterior notch, and pair of palps longer than prostomium (Figures 9a,c and 10a,b). Median antenna and palps all smooth. Prostomium lacking frontal filaments, lateral antennae, and eyes. Two pairs of jaws with numerous small teeth; five pairs of terminal papillae on proboscis, surrounding the mouth (Figure 11b). First segment fused to prostomium, with two pairs of short anterior cirri. (Figures 9a,c and 11a,b). All anterior cirri, antenna, and palps smooth. Ten pairs of elytra attached anteriorly to elytrophores on Segments 2, 4, 5, 7, 9, 11, 13, 15, 17, and 19 (Figures 9a and 10a). Elytra small, oval or irregularly oval, smooth, without border papillae (Figures 9a, 10c and 11a). Elytra partially or completely cover the parapodia but leaving most of dorsum uncovered. Non-elytrigerous Segments with cylindrical cirrophores and long smooth dorsal cirri, gradually tapering, extending slightly past neurochaetae, much longer than anterior and ventral cirri (Figures 9a and 11a). Branchiae dense and arborescent, with short terminal filaments, emerging dorsally on the parapodium in two groups; dorsal group larger in volume (Figures 9a and 11c-e). Branchiae on all segments from Segment 2 for females, increasing in size to completely cover parapodia, largest on Segments 9 and 11; smaller again on posterior segments. No discernible dorsal tubercles. Parapodia biramous, notopodia slightly smaller than neuropodia, with few notochaetae (Figure 11c). Notochaetae smooth, curved distally and with a rounded tip; shorter and stouter than neurochaetae (Figure 11c,e). Notopodial acicular lobe straight, long, reaching tip of notochaetae. Neuropodia deeply cleft, with rounded lobes and no protruding aciculum. Neurochaetae numerous, arranged as a fan. Neurochaetae long and slender with tapered tip and a subdistal swelling bordered by two longitudinal rows of spines (Figure 11f,g). 
No clear separation or difference in shape between sub- and supra-acicular neurochaetae, although subdistal area about twice as long in supra-acicular than subacicular neurochaetae. Ventral cirri small, smooth, shorter than anterior cirri, attached to middle of neuropodia (Figures $9 \mathrm{~b}$ and 10b). Ventral cirri on Segment 2 longer than following (Figures $9 \mathrm{~b}$ and 10b), projecting anteriorly. Elongated ventral papillae of holotype on Segments 11 and 12 project posteriorly, nearly reaching the end of the following segments (Figure 9b); those on males on Segment 12 (Figure 10b). Segments 20 and 21 slightly reduced in size in males. Pygidium small, paired short anal cirri (Figures 9a,b and 10a,b). Anus terminal.
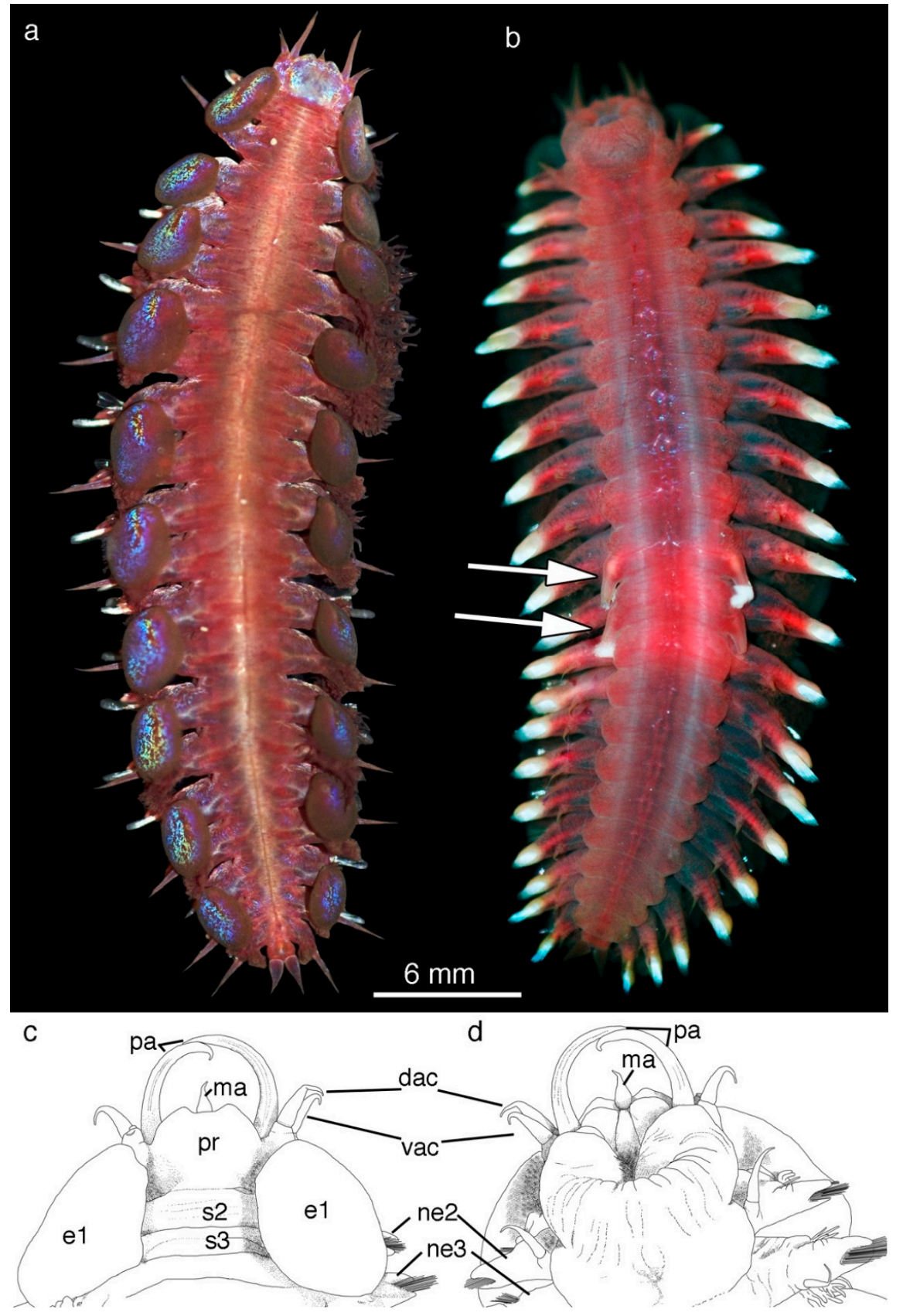

Figure 9. Branchipolynoe halliseyae n. sp. female holotype (SIO-BIC A1322) (a) Dorsal view. (b) Ventral view. Arrows indicate elongated ventral papillae of Segments 11 and 12. (c) Drawing of dorsal anterior. (d) Drawing of ventral anterior. Abbreviations: pa, palps; ma, median antenna; pr, prostomium; e1, first elytron (attached on Segment 2); s2 and s3, Segments 2 and 3; dac, dorsal anterior cirrus; vac, ventral anterior cirrus; ne2 and ne3, neuropodia 2 and 3; vc2, ventral cirrus on Segment 2. 


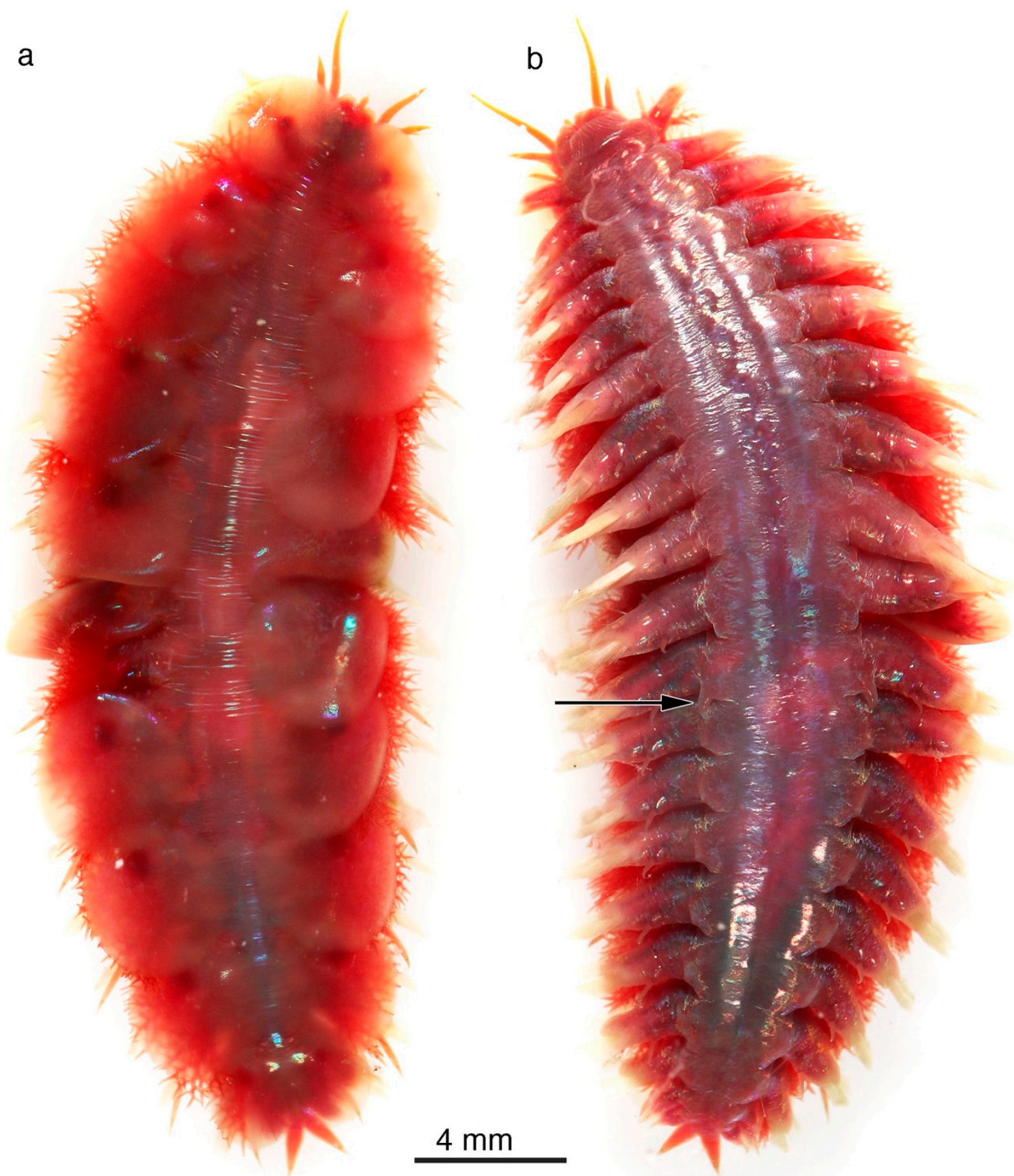

Figure 10. Branchipolynoe halliseyae n. sp. live male paratype (SIO-BIC A6690). (a) Dorsal view. (b) Ventral view. Arrow indicates elongated ventral papilla of Segment 12. 

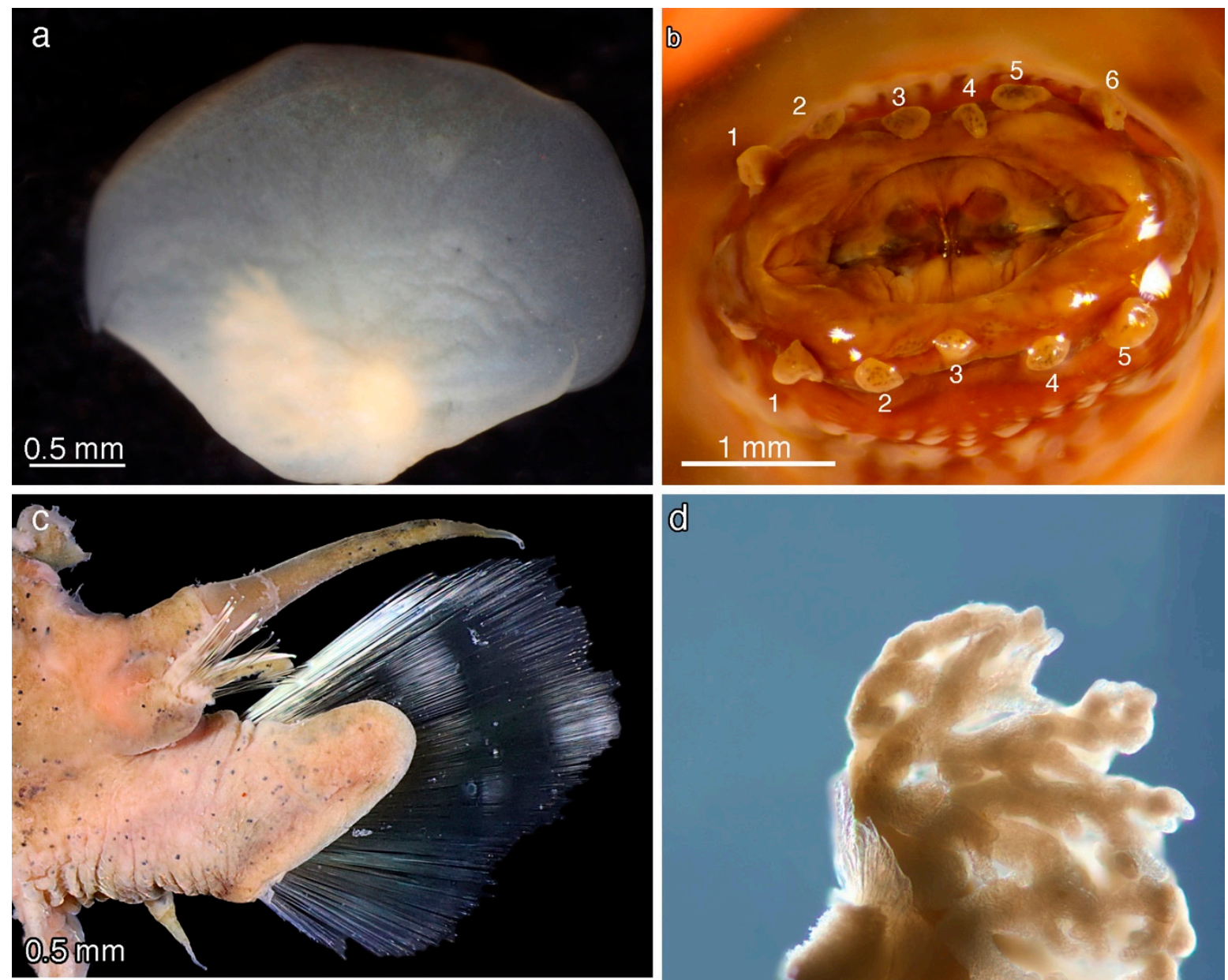

[]
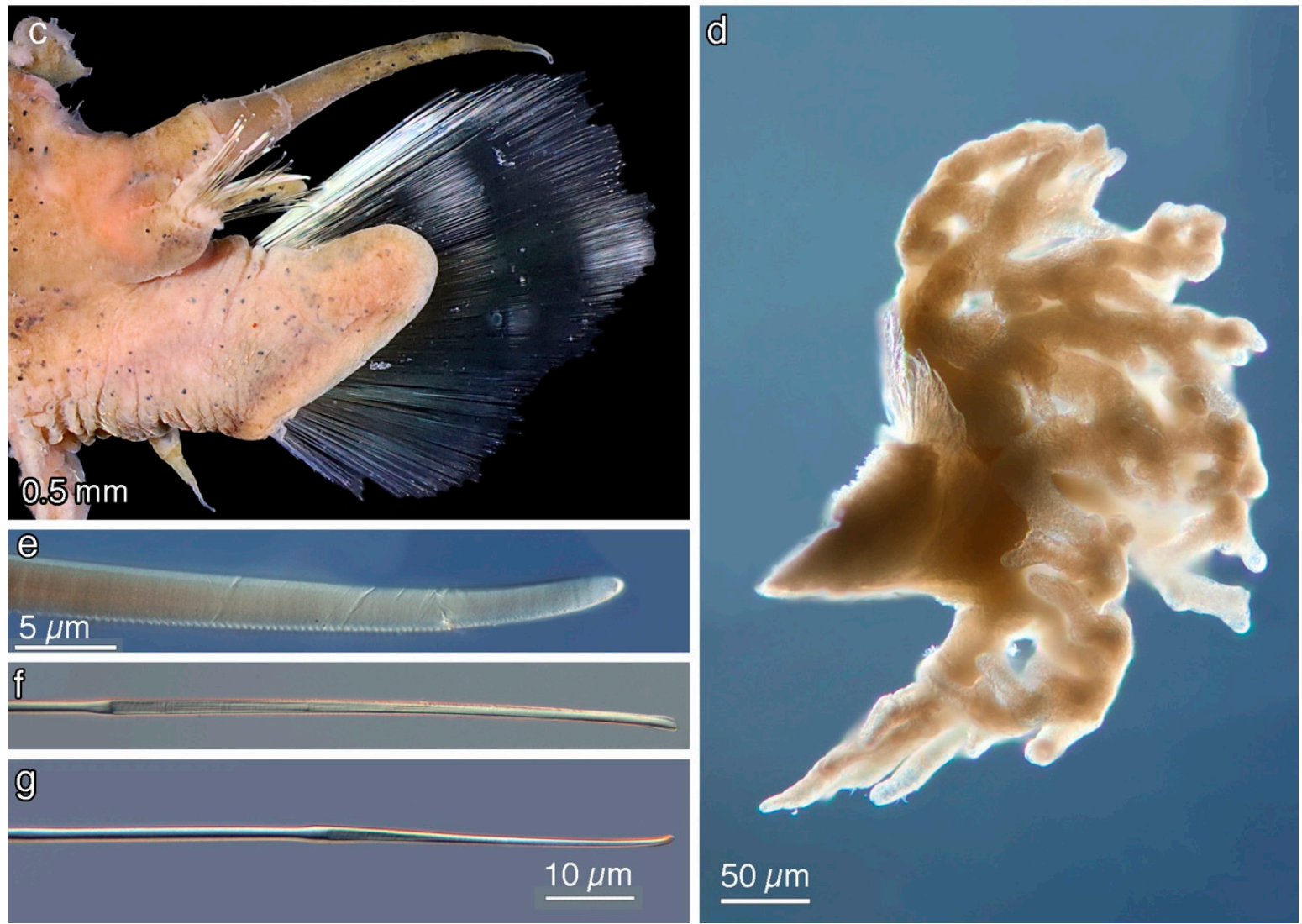

@)

\section{$\underline{10 \mu \mathrm{m}}$}

Figure 11. Branchipolynoe halliseyae n. sp. preserved female paratypes (all SIO-BIC A6540, except for proboscis). (a) Elytron from Segment 15. (b) Frontal view of proboscis showing papillae and jaws (SIO-BIC A6568). (c) Parapodium from Segment 14 with dorsal cirrus. (d) Branchia from Segment 7 (dorsal group). (e) Notochaeta (Segment 16). (f) Supra-acicular neurochaetae (Segment 14). (g) Subacicular neurochaeta (Segment 14). Same scale for $(\mathbf{f}, \mathbf{g})$.

Morphological variation-The majority of specimens were female, except for three males, which had a single pair of elongated ventral papillae (on Segment 12). Males have no branchiae on segments after the last elytra. The holotype was $43 \mathrm{~mm}$ long, $17 \mathrm{~mm}$ wide, including parapodia. Females varied in size from 21-74 $\mathrm{mm}$ long and 7-28 mm wide. The males ranged in size from 22-32 $\mathrm{mm}$ long and 9-12 mm wide. One paratype has an extra terminal papilla on proboscis (Figure 11b).

Remarks-Branchipolynoe halliseyae n. sp. can be difficult to distinguish morphologically from its sister taxon B. kajsae n. sp. (Figure 1). However, a striking difference is the development of the 
notoacicular lobe: in $B$. halliseyae n. sp., it reaches the tips on the notochaetae while it only reached half of length of notochaetae in B. kajsae n. sp. More subtle differences include the notochaetae of $B$. halliseyae n. sp. that appear more curved than those of B. kajsae n. sp. Moreover, the notochaetae of $B$. halliseyae n. sp. have a subdistal swelling that is absent in B. kajsae n. sp. Both species were found in all three Bathymodiolus species occurring at the Costa Rican seeps and at depths from 1000-1800 m. The B. halliseyae n. sp. and B. kajsae n. sp. clade is closest to the Gulf of Mexico B. seepensis (Figures 1 and 3). Apart from the geographic isolation and molecular distance, they differ from this species in having branchiae starting on Segment 2 instead of 3, parapodial structures (size and shape of notopodium), and longer dorsal cirri (Table 4).

\section{Branchipolynoe kajsae, new species Figures 12-14}

Material-Costa Rica, Eastern Pacific, associated with Bathymodiolus mussels near methane seeps. Holotype female (SIO-BIC A6611): Mound 12, 8.93 N, 84.31 W, 1000 m, Alvin Dive 4909, 24 May 2017, collectors E. Cordes \& R. Smith. Paratypes females, except where indicated (SIO-BIC A2159-A2162, A6516-A6520): Jaco Scarp, 9.12 ${ }^{\circ} \mathrm{N}, 84.84^{\circ} \mathrm{W}, 1800 \mathrm{~m}$, Alvin Dive 4590, 11 January 2010, collector G. Rouse, 9 specimens. Paratypes (SIO-BIC A6574, A6597): Mound 12, 8.93 N, 84.31 ${ }^{\circ}$ W, 999 m, Alvin Dive 4907, 22 May 2017, collectors L. Levin \& C. Seid, 2 specimens. Paratype (SIO-BIC A6626): 8.93 N, 84.31 W, 1004 m, Alvin Dive 4910, 25 May 2017, collectors G. Rouse \& T. Litke, 1 specimen. Paratypes (SIO-BIC A6652, A6669, MZUCR 405-01): Jaco Scar, 9.12 ${ }^{\circ} \mathrm{N}, 84.84^{\circ} \mathrm{W}, 1886 \mathrm{~m}$, Alvin Dive 4914, 29 May 2017, collectors C. Roman \& A. Durkin, 3 specimens. Paratype male (SIO-BIC A6703): Mound 12, $8.93^{\circ} \mathrm{N}, 84.32^{\circ} \mathrm{W}, 1000 \mathrm{~m}$, Alvin Dive 4917, 1 June 2017, collectors G. Rouse \& B. Moran, 1 specimen. Paratype (SIO-BIC A6662): 8.93 N, 84.31 ${ }^{\circ} \mathrm{W}, 1009$ m, Alvin Dive 4922, 5 June 2017, collectors J. Le \& C. Roman, 1 specimen. Paratypes (SIO-BIC A6707, A6710, A6712, A6713): Quepos Seep, 9.03 ${ }^{\circ} \mathrm{N}, 84.62^{\circ}$ W, 1409 m, Alvin Dive 4924, 7 June 2017, collectors L. Levin \& K. Krasnosky, 4 specimens.

Etymology-Named in honor of Carin "Kajsa" Lindgren, mother of the first author.

Host-Bathymodiolus sp. 1, 2, 3 (McCowin et al. in prep.).

Description-Body long, slightly tapered posteriorly. Adults with 21 Segments, including first achaetous segment (Figure 12a,b and Figure 13a,b). Prostomium bilobed with rounded anterior lobes, short conical median antenna inserted directly into a shallow anterior notch, and pair of slender palps longer than prostomium (Figures $12 \mathrm{a}-\mathrm{c}$ and $13 \mathrm{a}, \mathrm{b}$ ). Prostomium lacking frontal filaments, lateral antennae, and eyes. Five pairs of terminal papillae on proboscis surrounding mouth opening; two pairs of jaws lined with small teeth (Figure 14b). First segment achaetous, fused to the prostomium, with two pairs of smooth, short anterior cirri (Figures 12a,b and 13a,b). All anterior cirri, median antenna, and palps smooth. Ten pairs of elytra attached anteriorly to elytrophores on Segments 2, 4, 5, 7, 9, 11, 13, 15, 17, and 19 (Figures 12a and 14a). Elytra small, ellipsoidal, and smooth, without border papillae (Figures 12a,c, 13b and 14a,e). Elytra leaving most of dorsum uncovered, ranging from partially covering to completely covering the parapodia, largest on Segments 9 and 11 (Figures 12a,c, $13 \mathrm{a}$ and $14 \mathrm{a}, \mathrm{e})$. Non-elytrigerous segments with smooth cylindrical cirrophores and long, slender, smooth dorsal cirri, gradually tapering, extending past tip of chaetae, much longer than anterior and ventral cirri (Figures 12a, 13a and 14c,e). Branchiae on all segments from Segment 2 in males and females, largely covering parapodia (Figures 12a, 13a and 14c-e). Dense and arborescent branchiae with short terminal filaments emerging from the body in two groups per parapodium; dorsal group larger in volume (Figures 12a and 13d,e). No discernible dorsal tubercles. Parapodia biramous (Figure 14c). Notopodia slightly smaller than neuropodia, with fewer notochaetae. Notopodial acicular lobe straight and short, only reaching half the length of notochaetae. Notochaetae shorter and stouter than neurochaetae, nearly smooth with rows of barely raised spines and with a rounded tip (Figure 14c,f). Neurochaetae numerous, arranged as a vertical fan. Neurochaetae long and slender with tapered tip and a subdistal swelling with longitudinal rows of spines along the edge (Figure 14g,h). No clear separation or difference in shape between sub- and supra-acicular neurochaetae, other than the length of the subdistal part (Figure 14c,g,h). Ventral cirri small, smooth, attached to middle of neuropodia, 
shorter than anterior cirri (Figure 12b,d). Ventral cirri from Segment 2 longer than following ones and projecting forward (Figures 12b and 13b). Elongated ventral papillae of female holotype on Segments 11 and 12 projecting posteriorly, each pair reaching nearly one-third the length of following segment (Figure 12b). Elongated ventral papillae on male paratype on Segment 12 only (Figure 13b). In males, Segments 20 and 21 reduced in size compared to females, and lacking branchiae. Pygidium small with pair of thick, tapered anal cirri (Figure 14e). Anus terminal (Figure 14e).

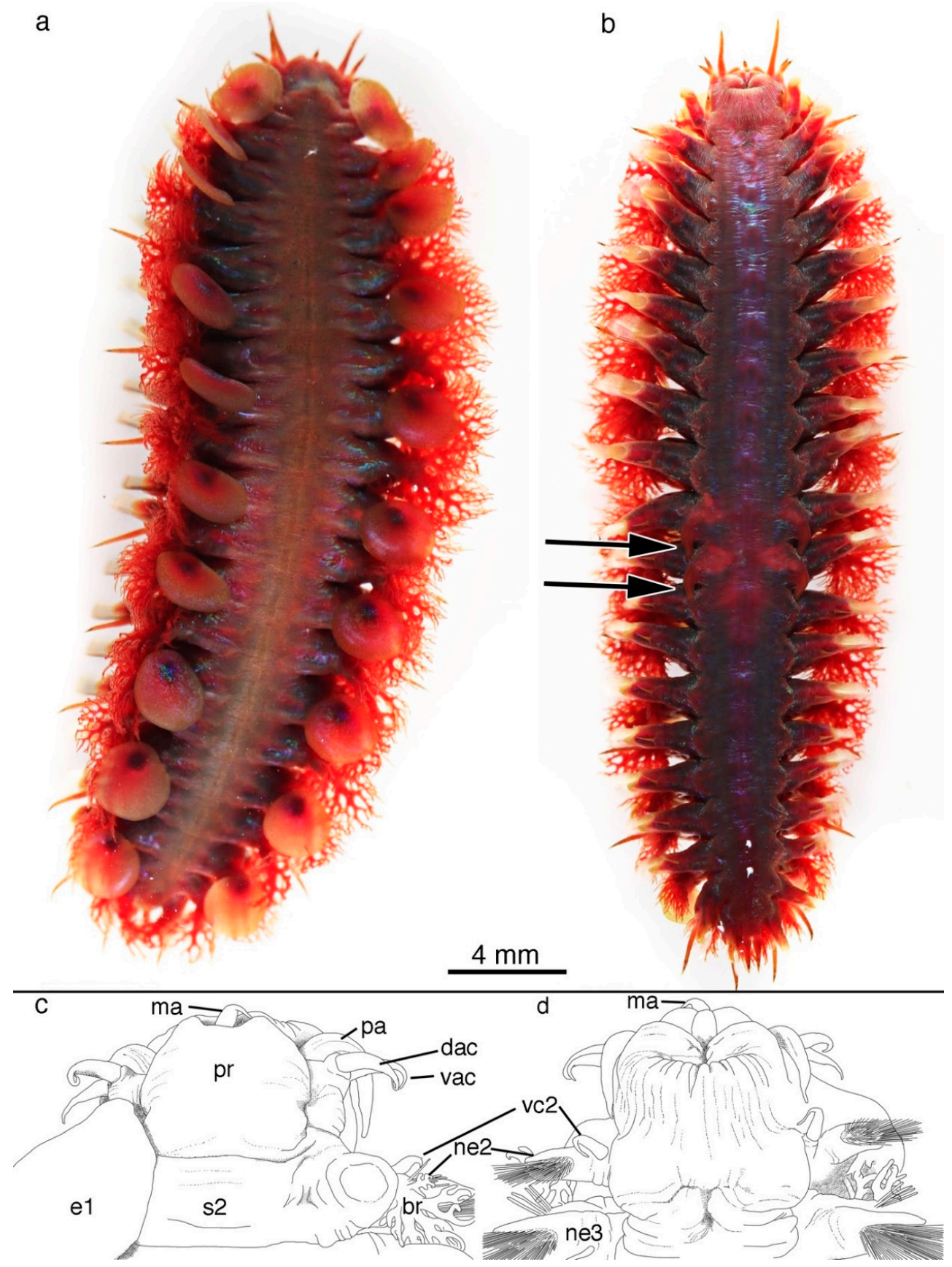

Figure 12. Branchipolynoe kajsae n. sp. female holotype (SIO-BIC A6611) (a) Dorsal view. (b) Ventral view. Arrows indicate elongated ventral papillae of Segments 11 and 12. (c) Drawing of dorsal anterior. (d) Drawing of ventral anterior. Abbreviations: pa, palps; ma, median antenna; pr, prostomium; e1, first elytron (attached on segment 2); s2 and s3, Segments 2 and 3; dac, dorsal anterior cirrus; vac, ventral anterior cirrus; ne2 and ne3, neuropodia 2 and 3; vc2, ventral cirrus on segment 2. 
a

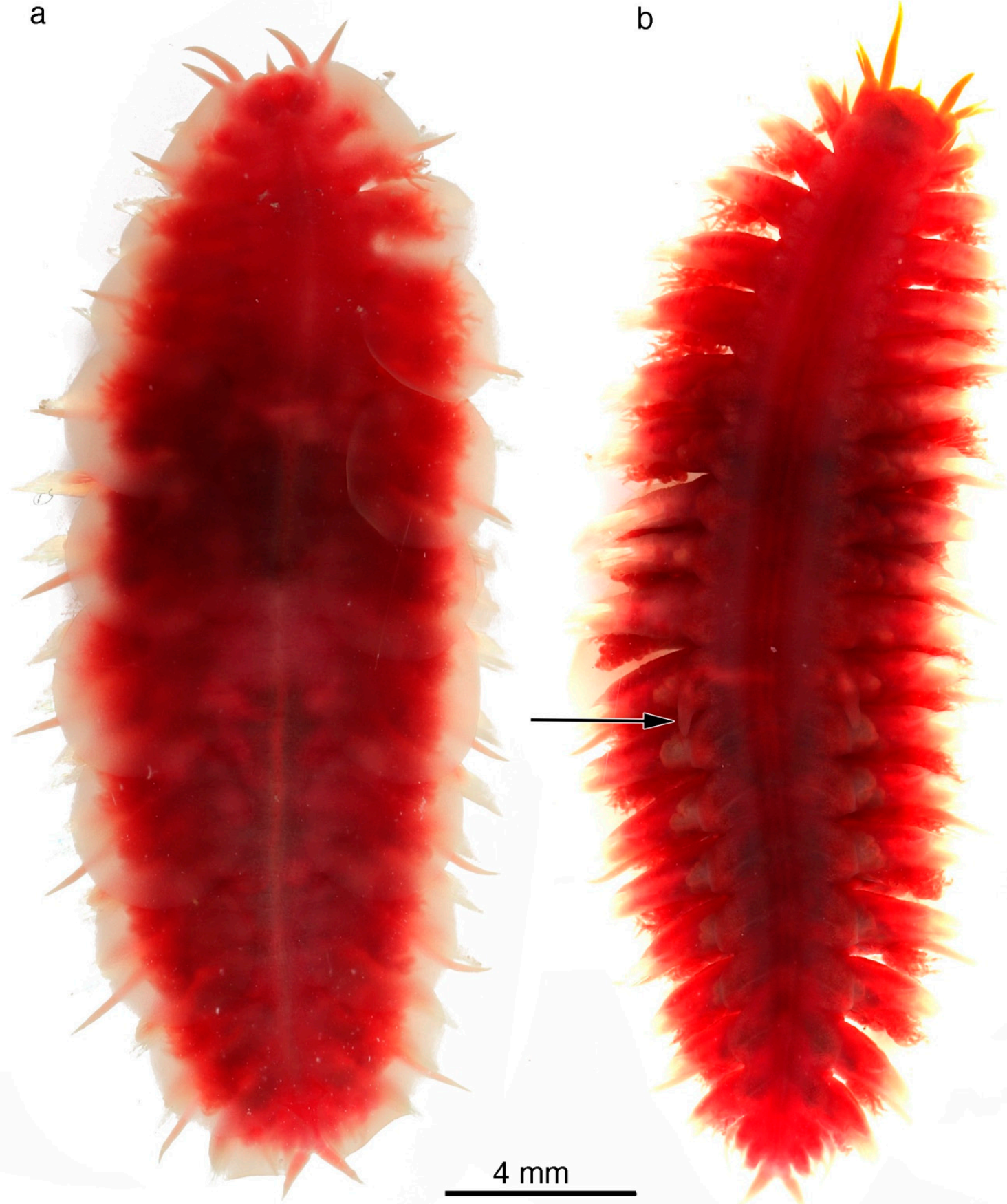

Figure 13. Branchipolynoe kajsae n. sp. live male paratype (SIO-BIC A6703). (a) Dorsal view. (b) Ventral view. Arrow indicates elongated ventral papilla of Segment 12. 

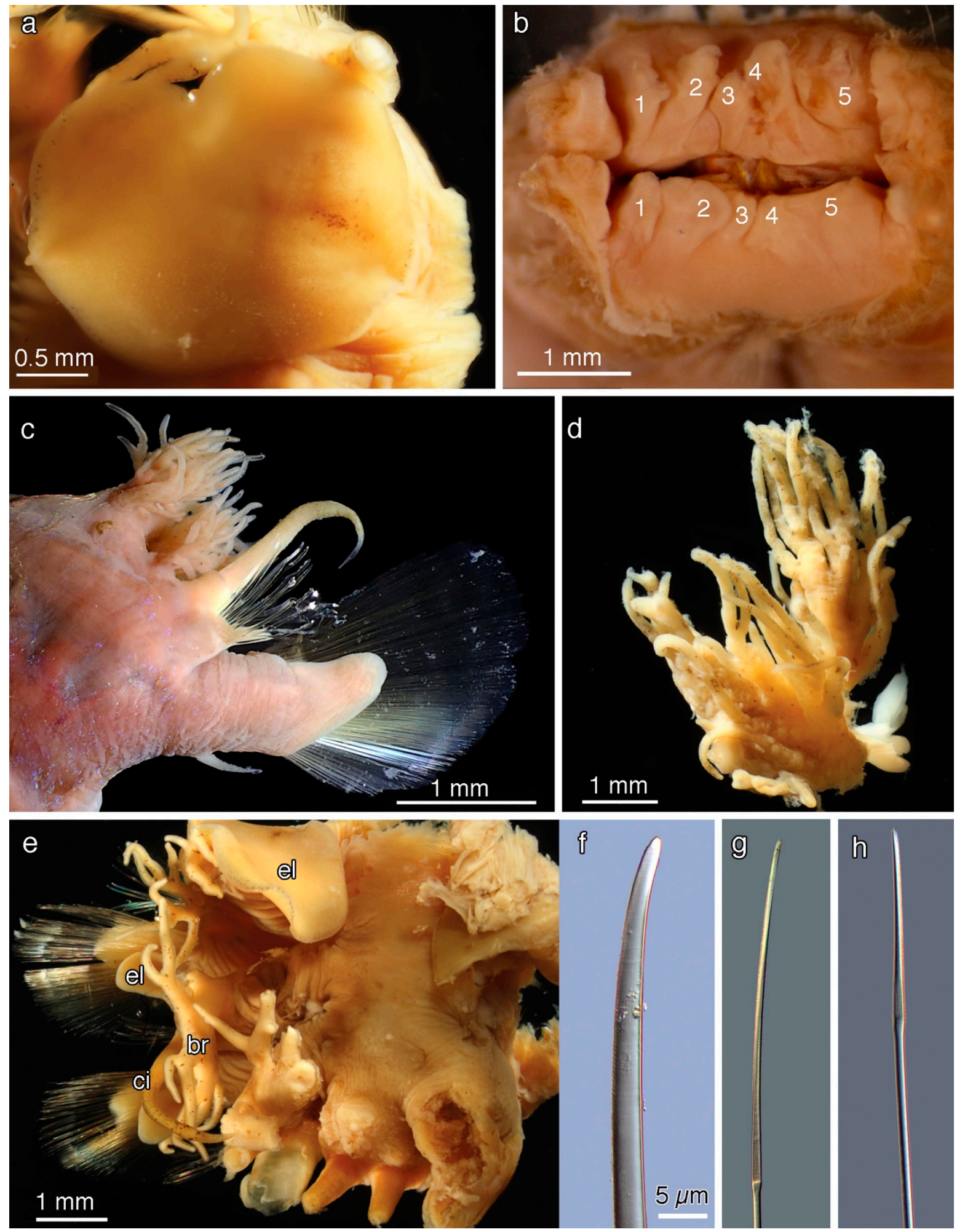

Figure 14. Branchipolynoe kajsae n. sp. female paratypes: (a) Elytron from segment 19 (SIO-BIC A6517). (b) Frontal view of proboscis showing papillae and jaws (SIO-BIC A6669). (c) Parapodium from Segment 14 with dorsal cirrus (SIO-BIC A2160). (d) Branchia (dorsal and ventral groups) from Segment 19 (SIO-BIC A6517). (e) Posterior part of individual SIO-BIC A2160 (Segments 20 and 21) and pygidium with a pair of anal cirri terminally. (f) Notochaeta (Segment 14; SIO-BIC A6662). (g) Supraacicular neurochaeta (Segment 14; SIO-BIC A6662). (h) Subacicular neurochaeta (segmental 14; SIO-BIC A6662). Same scale for $(\mathbf{f}-\mathbf{h})$. br, branchia; ci, parapodial cirrus; el, elytron. 
Morphological variation-The holotype is $35 \mathrm{~mm}$ long, $15 \mathrm{~mm}$ wide, including parapodia. Paratypes vary in size from 23-62 $\mathrm{mm}$ long and from 8-24 mm wide. One male paratype with a pair of elongated ventral papillae on Segment 12, $28 \mathrm{~mm}$ long and $9 \mathrm{~mm}$ wide. There was some variation in the segment on which branchiae begin. Five, including the holotype, clearly have them starting on Segment 2. Four paratypes were damaged and it is not clear, but they may also be on Segment 2. However, four paratypes have branchiae starting on Segment 3. Other Branchipolynoe species described to date are consistent on the starting segment for branchiae (Table 4).

Remarks-Branchipolynoe kajsae n. sp. is the sister group to B. halliseyae n. sp. (Figure 1) and they are morphologically similar. However, a striking difference is the development of the notopodial acicular lobe: in B. halliseyae n. sp., it reaches the tips on the notochaetae while it only reached half of length of notochaetae in B. kajsae n. sp. More subtle differences include the notochaetae of $B$. kajsae $\mathrm{n}$. $\mathrm{sp}$. that appear to be straighter than those of B. halliseyae n. sp. The B. kajsae n. sp. and B. halliseyae n. sp. clade is closest to the Gulf of Mexico B. seepensis (Figures 1 and 3). Apart from the geographic isolation and molecular distance, B. kajsae n. sp. and B. halliseyae n. sp. differ from B. seepensis in having branchiae starting on Segment 2 instead of 3, except for a few specimens of B. kajsae n. sp. in which the starting segment is 3 . The structure of the parapodia (size and shape of the notopodia and neuropodia) also differ. Finally, the dorsal cirri are longer and extend beyond the mass of branchiae, clearly distinguished dorsally in B. kajsae n. sp. and B. halliseyae n. sp. (Table 4).

\section{Branchipolynoe meridae, new species Figures 15 and 16}

Material-Costa Rica, Eastern Pacific, from dives of Alvin in 2009, 2010, and 2017, associated with Bathymodiolus mussels near methane seeps. Holotype (SIO-BIC A6616): Jaco Scar, $9.12^{\circ} \mathrm{N}, 84.85^{\circ} \mathrm{W}$, 1891 m, Alvin Dive 4911, 26 May 2017, collectors L. Levin \& J. Le. Paratype (SIO-BIC A6521): Mound $12,8.93^{\circ} \mathrm{N}, 84.31^{\circ} \mathrm{W}, 1008 \mathrm{~m}$, Alvin Dive 4501, 22 February 2009, collectors G. Rouse \& D. Huang, 1 specimen. Paratype (SIO-BIC A6523): Mound 12, 8.93 N, 84.31 ${ }^{\circ} \mathrm{W}, 1001 \mathrm{~m}$, Alvin Dive 4511, 5 March 2009, collectors G. Rouse \& D. Huang, 1 specimen. Paratypes (SIO-BIC A6524-A6529): Mound 12 (Yettisburgh), 8.93 N, 84.31 ${ }^{\circ} \mathrm{W}, 1000 \mathrm{~m}$, Alvin Dive 4586, 7 January 2010, collector G. Rouse, 6 specimens. Paratype (SIO-BIC A2131): Jaco Scarp, $9.12^{\circ} \mathrm{N}, 84.84^{\circ} \mathrm{W}, 1802 \mathrm{~m}$, Alvin Dive 4591, 12 Jan 2010, collector G. Rouse, 1 specimen. Paratype (MZUCR 404-02): Mound 12, 8.93 N, 84.31 W, $999 \mathrm{~m}$, Alvin Dive 4907, 22 May 2017, collectors L. Levin \& C. Seid, 1 specimen.

Etymology—Named after Merida from Disney/Pixar movie "Brave", due to the resemblance of its branchiae to her hair.

Host-Bathymodiolus sp. 1 and 3 (McCowin et al. in prep.).

Description-Body relatively short and wide, tapered anteriorly and posteriorly, with 21 Segments, including first achaetous segment (Figure 15a,b). Prostomium nearly unilobed with barely discernible rounded anterior lobes, without frontal filaments, lateral antennae, or eyes. Prostomium with short conical median antenna directly inserted in a small anterior notch, and a pair of tapered palps shorter than prostomium (Figure 15a-e). Both median antenna and palps about one third to one half of the length of the prostomium (Figure 15a-c). Five pairs of terminal papillae on proboscis, surrounding the mouth opening; two pairs of jaws lined with small teeth (Figure 16f). First segment fused to prostomium, with two pairs of short (about half the length of prostomium) anterior cirri (Figure 15a,b). All anterior cirri, palps, and median antenna smooth (Figure 15a-c). Ten pairs of elytra attached anteriorly to elytrophores on Segments 2, 4, 5, 7, 9, 11, 13, 15, 17, and 19 (Figures 15a,b and 16a,b). Elytra reniform, smooth, without border papillae, and very small to minute, barely wider than elytrophore, largest on Segment 1 (Figures 15a,b and 16a,b). Non-elytrigerous segments with smooth cylindrical cirrophores and smooth, tapered dorsal cirri, longer than anterior and ventral cirri. Dorsal cirri not extending beyond branchiae and neurochaetae (Figure 16c). Branchiae on all segments from Segment 2. Branchiae arborescent with long terminal filaments, attached in two groups per parapodium, dorsal one larger in volume (Figure 16a,c,d) and smaller ventral one (Figure 16a,c,e). Branchiae small on Segment 2, much larger on following segments (Figures 15a,b and 16a,c-e). No discernible dorsal tubercles. Parapodia 
subbiramous with minute notopodia bearing short, tapered, smooth and blunt notochaetae (Figure 16c). Notopodial acicular lobe very short, rounded. Neuropodial acicular lobe short and triangular, not deeply cleft. Neuropodia larger than notopodia with short and slender neurochaetae arranged as a fan (Figure 16g). Clear separation between supra- and subacicular neurochaetae. Subacicular neurochaetae slenderer than supra-acicular neurochaetae. Both neurochaetae groups with subdistal swelling, but with a shorter subdistal region and a terminal curved tooth for the supra-acicular neurochaetae, and a longer subdistal region and a rounded tip for subacicular neurochaetae. (Figure 16a,c). Ventral cirri small, smooth, shorter than anterior cirri, and attached to middle of neuropodia (Figures 15c and 16a,c). Ventral cirri on Segment 2 slightly longer than following ones, and directed anteriorly (Figure 15c,e). Females with elongated ventral papillae on Segments 11 and 12 projecting posteriorly, barely reaching one-third of the length of the following segment (Figure 15c). Males unknown. Pygidium small with pair of short, thin anal cirri (Figure 15c). Anus terminal.

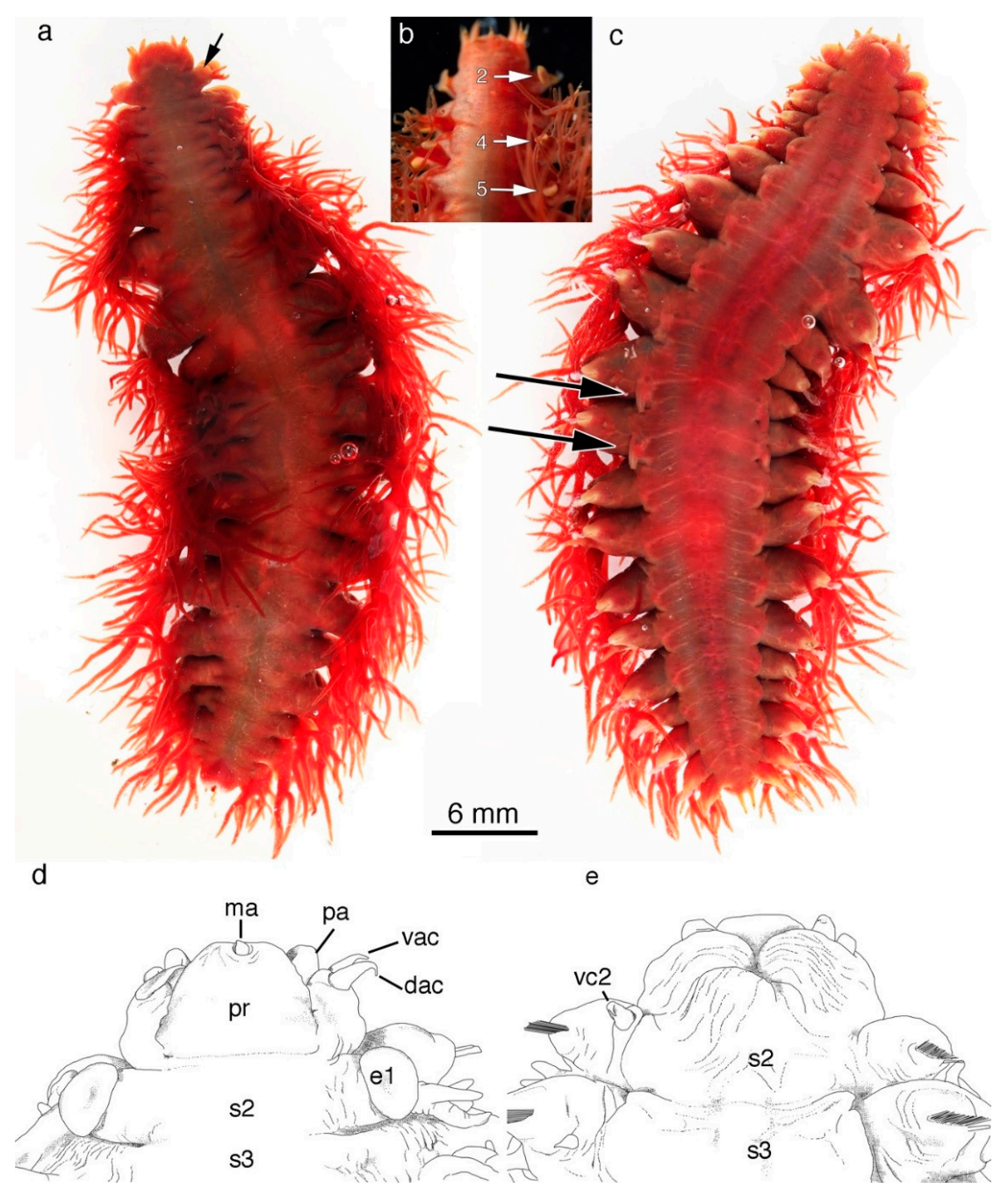

Figure 15. Branchipolynoe meridae n. sp. live female holotype (SIO-BIC A6616) and paratype (SIO-BIC A6529). (a) Dorsal view of holotype. Arrow indicates the very small elytron on segment 2. (b) Dorsal view of anterior of live paratype SIO-BIC A6529 showing small elytra on Segments 2, 4, and 5. (c) Ventral view of holotype. Arrows indicate elongated ventral papillae of Segments 11 and 12. (d) Drawing of dorsal anterior. (e) Drawing of ventral anterior. Abbreviations: pa, palps; ma, median antenna; pr, prostomium; e1, first elytron (attached on segment 2); s2 and s3, Segments 2 and 3; dac, dorsal anterior cirrus; vac, ventral anterior cirrus; vc2, ventral cirrus on segment 2. 

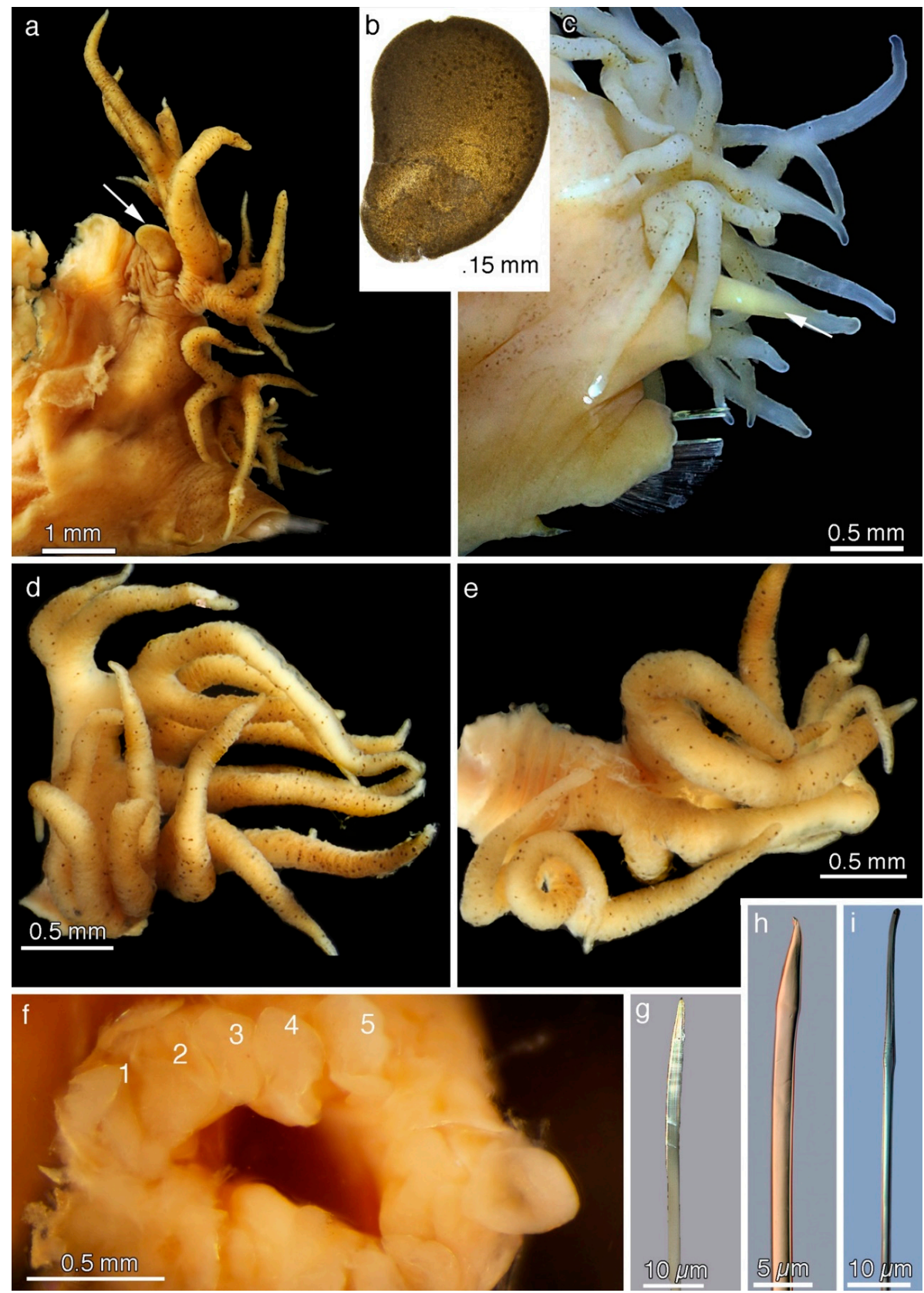

Figure 16. Branchipolynoe meridae n. sp. preserved female paratypes (all SIO-BIC A6521, except for proboscis): (a) Parapodium from Segment 15 with elytron (arrow). (b) Elytron from Segment 13. (c) Parapodium from Segment 8 with dorsal cirrus (arrow). (d) Branchia from Segment 12 (dorsal group). (e) Branchia from Segment 12 (ventral group). (f) Frontal view of proboscis showing papillae (MZUCR 404-02). (g) Notochaeta (Segment 16). (h) Supra-acicular neurochaeta (Segment 8). (i) Subacicular neurochaeta (Segment 8).

Morphological variation-The holotype is $50 \mathrm{~mm}$ long, $20 \mathrm{~mm}$ wide including parapodia. Paratypes vary in size from $27-29 \mathrm{~mm}$ long and from $11-15 \mathrm{~mm}$ wide.

Remarks-Branchipolynoe meridae $n$. sp. has very small elytra, long filamentous branchiae, and nearly unilobed prostomium, and is easily distinguished from its closest relatives, B. eliseae n. sp. and B. symmytilida on these features. They also distinguish it from the two other sympatric species $B$. kajsae n. and B. halliseyae n. sp. (Table 4).

\section{Branchipolynoe tjiasmantoi, new species}




\section{Figures 17-19}

Type Material-Western Pacific hydrothermal vents near Fiji, Tonga, and Vanuatu. Dives of ROV Jason II in 2005 and ROV Quest in 2013, found in Bathymodiolus mussels. Holotype (SIO-BIC A5460): North Fiji Basin, White Lady hydrothermal vent, $16.99^{\circ}$ S, 173.91 W, 1991 m, Jason II Dive 149, 27-28 May 2005, collector R. Vrijenhoek. Paratype (SIO-BIC A4009): details same as holotype, 1 specimen. Paratypes (SIO-BIC A4010, A4011A, A4011B): North Fiji Basin, White Lady hydrothermal vent, $16.99^{\circ}$ S, 173.91 W, 1973 m, Jason II Dive 150, 29 May 2005, collector F. Pleijel, 3 specimens. Paratype (SIO-BIC A8511): Kilo Moana, Lau Back-arc Basin, Tonga $20.05^{\circ}$ S, $176.13^{\circ}$ W, 2657 m, Jason II Dive 141, 18 May 2005, collector R. Vrijenhoek, 1 specimen. Paratype (SIO-BIC A7303A, male): New Hebrides Arc, Nifonea hydrothermal vent, $18.12^{\circ} \mathrm{S}, 169.52^{\circ} \mathrm{E}, 1868 \mathrm{~m}$, ROV Quest Station 27, 12 July 2013, collector K. Haase, 1 specimen. Paratypes (SIO-BIC A7309A-A7309K, A7310B, A7310C): New Hebrides Arc, Nifonea hydrothermal vent, $18.13^{\circ}$ S, $169.51^{\circ}$ E, 1873 m, ROV Quest Station 77, 22 July 2013, collector K. Haase, 13 specimens.

Other Material-Vouchers (SIO-BIC A9392): Niuatahi Seamount, Tonga-Tofua Arc, Tonga, $15.34^{\circ}$ S, $174.01^{\circ} \mathrm{W}, 1576 \mathrm{~m}$, RV Sonne with ROV Quest, 2018, Dive 437, collector T. Giguere. Vouchers (IA-2013-406-408): Vanuatu hydrothermal vent, New Hebrides Arc, $18^{\circ} 7.736^{\prime} \mathrm{S}, 169^{\circ} 31.110^{\prime} \mathrm{E}, 1871$ m, RV Sonne 229 Cruise with ROV Quest, 2013, Dive 120, collector K. Haase, 3 specimens. Voucher (IA-2013-340): Western Pacific hydrothermal vents of the Kermadec Arc, New Zealand. RV Sonne 253 Cruise with ROV Quest, 2017. Haungaroa hydrothermal vent $32^{\circ} 36.82^{\prime}$ S, $179^{\circ} 37.23^{\prime} \mathrm{E}, 674 \mathrm{~m}$, Dive 414, collector S. Hourdez, 1 specimen. Vouchers (IA-2013-338-9) Kermadec Arc, Brothers Caldera hydrothermal vent $34^{\circ} 51.92^{\prime}$ S, $179^{\circ} 3.52^{\prime}$ E, 1825 m, Dive 426 collector S. Hourdez, 2 specimens.

Etymology—Named in honor of Wewin Tjiasmanto, in appreciation for his support for the Scripps Oceanographic Collections.

Host-Bathymodiolus spp. including B. brevior (Hourdez pers. obs.)

Description-Holotype, adult with 21 Segments, including the first achaetous segment (Figure 17a,b). Prostomium bilobed with almost triangular anterior lobes, short conical median antenna directly inserted between the two lobes, and a pair of long, slender palps. Median antenna and palps smooth. Prostomium lacking frontal filaments, lateral antennae, and eyes (Figure 17a-f). Five pairs of terminal papillae on proboscis, dorsal and ventral to mouth (Figures 17e,f and 19b); two pairs of jaws (Figure 19b). First segment fused to the prostomium, with two pairs of short, smooth anterior cirri (Figure 17a-f). Ten pairs of elytra attached anteriorly to elytrophores on Segments 2, 4, 5, 7, 9, 11, 13, 15, 17, and 19 (Figure 17a and Figure 18a). Elytra oval and smooth (Figures 17a,c, 18a and 19a), leaving most of dorsum uncovered, though covering parapodia (Figures 17a,c and 18a). Non-elytrigerous segments with cylindrical cirrophores and long, slender dorsal cirri extending past chaetae (Figures 17a-c, 18a,b and 19c,d). Branchiae on all segments from Segment 3 (Figure 17a,c), some visible beyond the border of elytra. Branchiae dense and arborescent (Figures 17a and 19c-e) emerging as two groups above each parapodium; dorsal group larger in volume (Figure 19d,e). No discernible dorsal tubercles. Parapodia subbiramous (Figure 19c,d). Notopodia smaller than neuropodia, with one to few notochaetae (Figure 19d). Notochaetae smooth, shorter and stouter than neurochaetae (Figure 19f). Neurochaetae numerous, arranged as a vertical fan. Clear separation between supraand subacicular neurochaetae. Supra-acicular neurochaetae long, slender with tapered tip (Figure 19g); subacicular neurochaetae thick with hooked tip (Figure 19g). Elongated ventral papillae of female holotype on Segments 11 and 12, projecting posteriorly nearly reaching the end of the following segment (Figure 17b); those on male paratype on segment 12, only reaching about half the length of following segment (Figure 18b). Ventral cirri small, similar in size to anterior cirri, and attached to middle of neuropodia (Figures 17b,d and 18b). Pygidium small with pair of thick, tapered anal cirri (Figure 17a,b). Anus terminal.

Morphological variation-Holotype $33 \mathrm{~mm}$ long, $12 \mathrm{~mm}$ wide, including parapodia. Paratypes vary in size; $25-40 \mathrm{~mm}$ long and $11-15 \mathrm{~mm}$ wide. One male paratype with a pair of elongated ventral papillae on segment 12, $15 \mathrm{~mm}$ long and $5 \mathrm{~mm}$ wide (Figure 18). 
Remarks-Apart from the molecular data that distinguishes Branchipolynoe tjiasmantoi n. sp. as a new species, it also has a combination of unique morphological features. It has moderate-sized elytra and short, dense branchiae, while one of its closest relative B. pettiboneae has long filamentous branchiae [20], and the other, B. longqiensis, has different shaped neurochaetae (Table 4). Previous records of $B$. pettiboneae from the Fiji and Lau basins $[25,28]$ would appear to be $B$. tjiasmantoi n. sp.
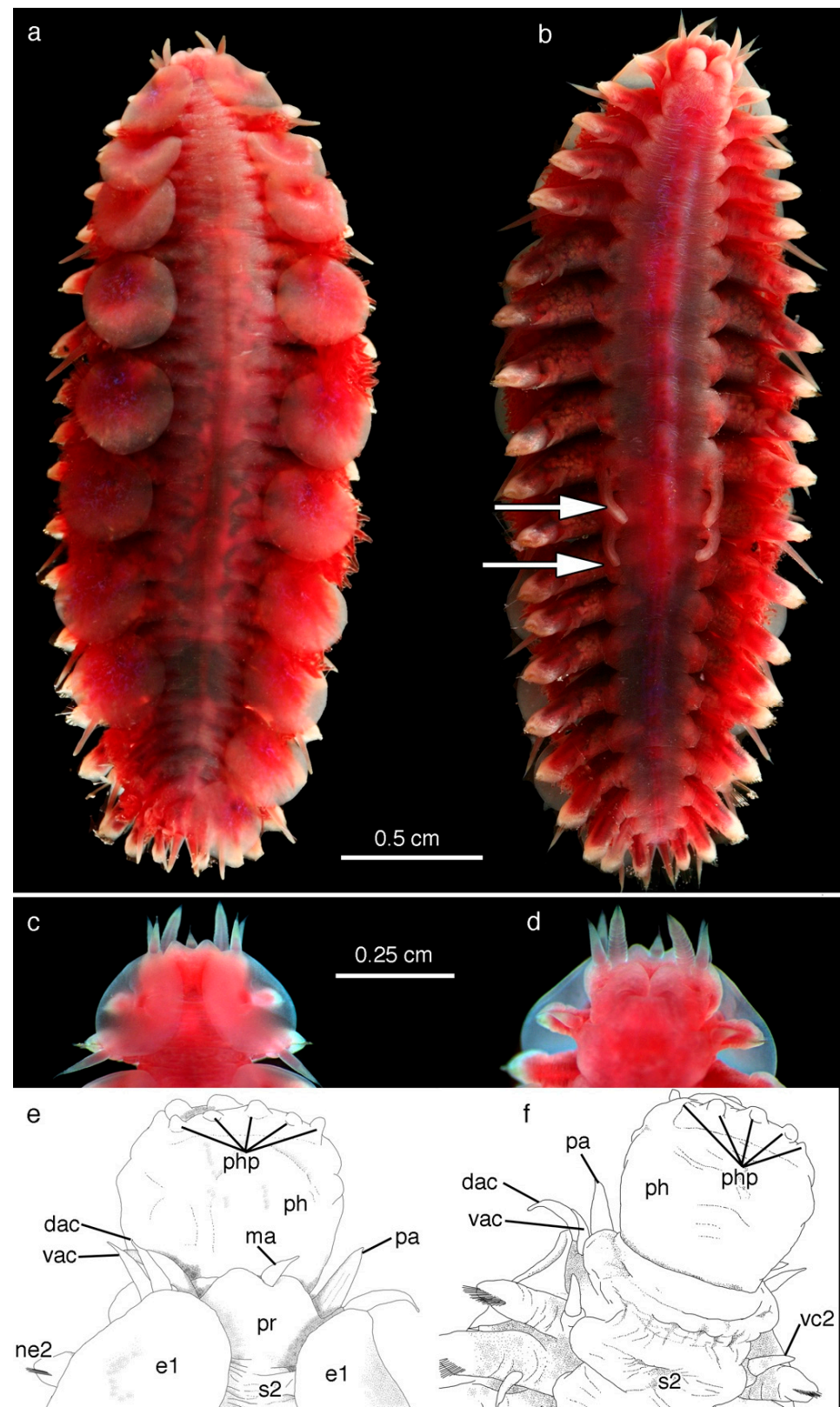

Figure 17. Branchipolynoe tjiasmantoi n. sp. live female holotype (SIO-BIC A5460) and live paratype (SIO-BIC A8511). (a) Dorsal view of holotype (SIO-BIC A5460). (b) Ventral view of holotype. Arrows indicate elongated ventral papillae of Segments 11 and 12. (c) Dorsal view of anterior of paratype head (SIO-BIC A8511). (d) Ventral view of anterior of paratype head. (e) Drawing of dorsal anterior holotype. (f) Drawing of ventral anterior holotype. Abbreviations: pa, palps; ma, median antenna; ph, pharynx; php, pharynx papillae; pr, prostomium; e1, first elytron (attached on segment 2); s2, segment 2; dac, dorsal anterior cirrus; vac, ventral anterior cirrus; vc2, ventral cirrus on segment 2. 


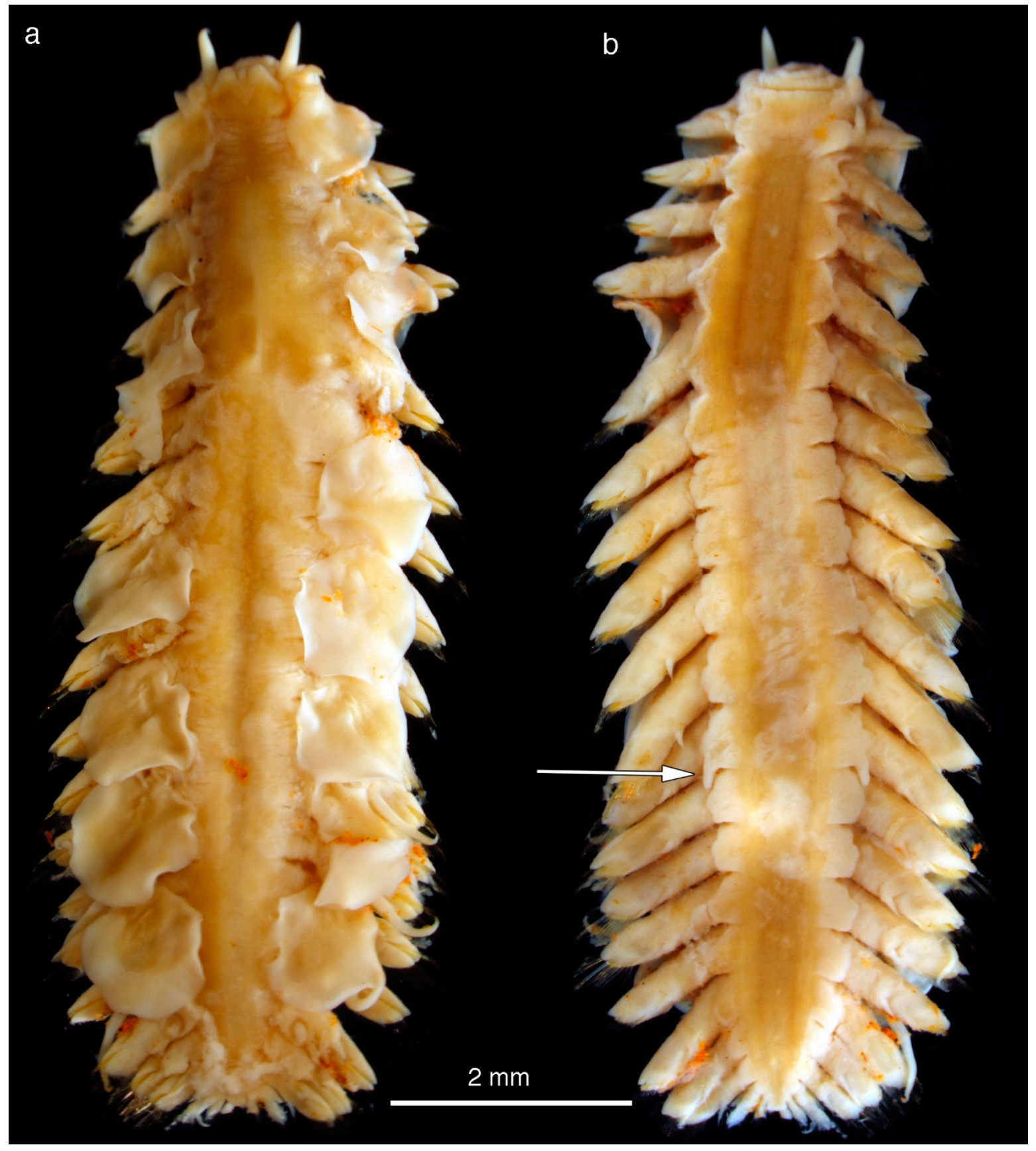

Figure 18. Branchipolynoe tjiasmantoi $n$. sp. preserved male paratype (SIO-BIC A7303A). (a) Dorsal view. (b) Ventral view. Arrow indicates one of the paired elongated ventral papillae on segment 12. 

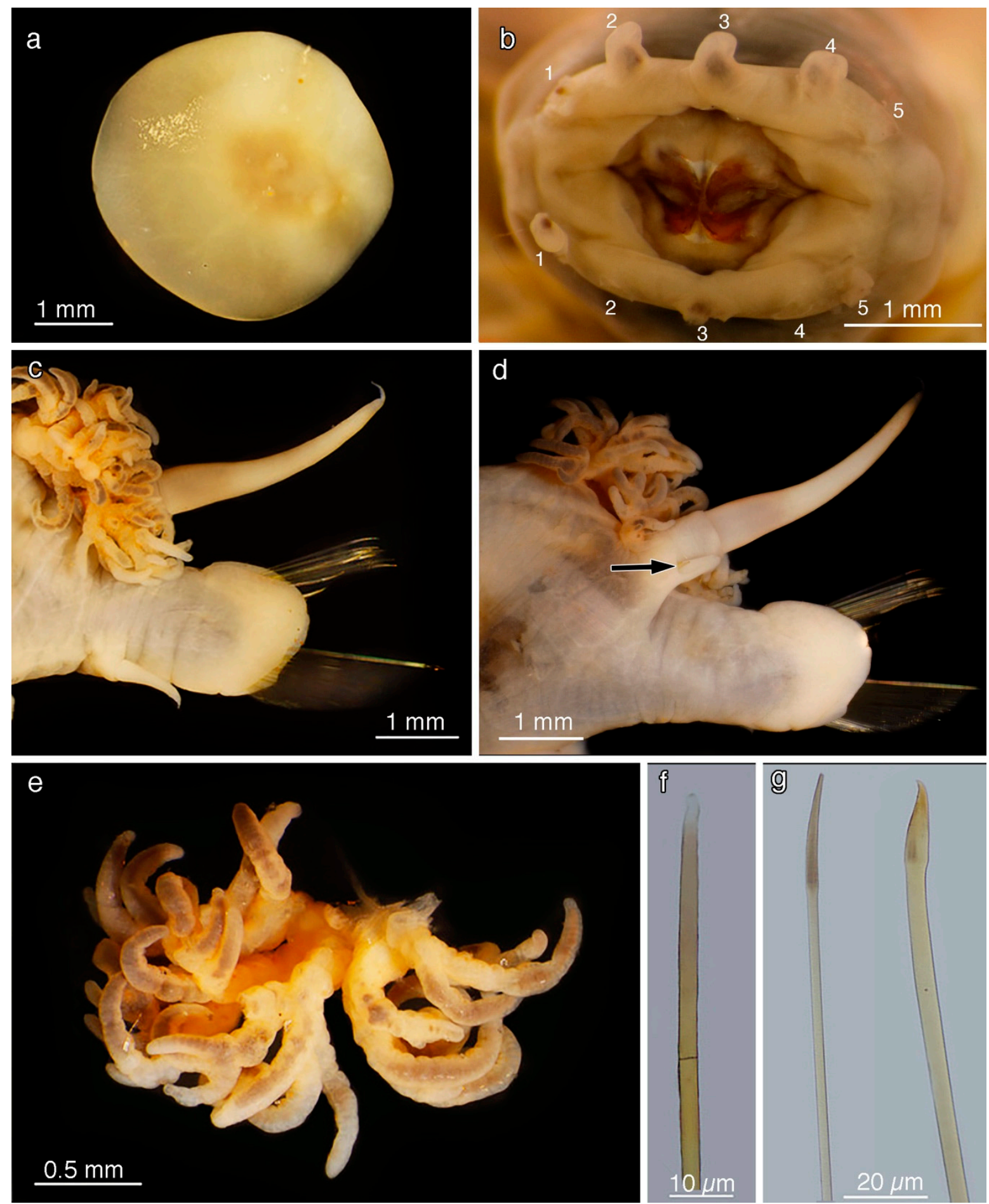

Figure 19. Branchipolynoe tjiasmantoi n. sp. preserved female holotype (SIO-BIC A5460). (a) Elytron from Segment 5. (b) Frontal view of proboscis showing papillae and jaws of holotype. (c) Parapodium from Segment 12 with dorsal cirrus, rostral view. (d) Parapodium from Segment 12 with dorsal cirrus, caudal view; arrow indicates notopodium. (e) Branchia from Segment 10. (f) Notochaeta (Segment 12). (g) Supraacicular neurochaeta (left) and subacicular neurochaeta (right) (Segment 12).

Author Contributions: G.W.R. and J.L. conceived the project. G.W.R. and C.A.S. collected specimens, except for $B$. seepensis and some B. tjiasmantoi n. sp., which were provided via S.H., J.L. and A.S.H. sequenced all the specimens, except for some B. tjiasmantoi n. sp. sequenced by S.H. J.L., A.S.H., and C.A.S. organized all of the samples and 
host information. J.L., S.H., and G.W.R. gathered the morphological data. G.W.R., J.L., and S.H. analyzed the data and wrote the paper. All authors approved the final version.

Funding: This project was funded by the US National Science Foundation (NSF OCE-0826254, OCE-0939557, OCE-1634172).

Acknowledgments: The authors are grateful to Chief Scientists Erik Cordes, Lisa Levin and Bob Vrijenhoek, the captains and crews of the R/V Atlantis and R/V Melville and the crew and pilots of the HOV Alvin and ROV Jason II for crucial assistance in specimen collection on cruises to Costa Rica seeps and West Pacific vents. On the Costa Rica cruises, Danwei Huang and Ben Moran were very helpful is gathering the Branchipolynoe specimens. Thanks also to Robert Vrijenhoek (MBARI) for inviting GWR on the cruise to various West Pacific hydrothermal vent localities. We are very grateful to Verena Tunnicliffe for providing specimens of Branchipolynoe tjiasmantoi $\mathrm{n}$. $\mathrm{sp}$. from Tonga and Vanuatu. We also thank Phil Zerofski and Sea Camp and Wewin Tjiasmanto for support for SIO and the SIO Collections. Finally, we thank the anonymous reviewers for their valuable suggestions.

Conflicts of Interest: The authors declare no conflict of interest.

\section{References}

1. Gonzalez, B.C.; Martínez, A.; Borda, E.; Iliffe, T.M.; Eibye-Jacobsen, D.; Worsaae, K. Phylogeny and systematics of Aphroditiformia. Cladistics 2017, 34, 225-259. [CrossRef]

2. Norlinder, E.; Nygren, A.; Wiklund, H.; Pleijel, F. Phylogeny of scale-worms (Aphroditiformia, Annelida), assessed from 18SrRNA, 28SrRNA, 16SrRNA, mitochondrial cytochrome c oxidase subunit I (COI), and morphology. Mol. Phylogenet. Evol. 2012, 65, 490-500. [CrossRef] [PubMed]

3. Zhang, Y.; Sun, J.; Rouse, G.W.; Wiklund, H.; Pleijel, F.; Watanabe, H.K.; Cheng, C.; Qian, P.Y.; Qiu, J.W. Phylogeny, evolution and mitochondrial gene order rearrangement in scale worms (Aphroditiformia, Annelida): Insights from low-coverage genome sequencing. Mol. Phylogenet. Evol. 2018, 125, $220-231$. [CrossRef] [PubMed]

4. WoRMS Editorial Board. World Register of Marine Species. 2018. Available online: http://www.marinespecies. orgatVLIZ (accessed on 8 June 2018).

5. Pettibone, M.H. Additional branchiate scale-worms (Polychaeta: Polynoidae) from Galapagos hydrothermal vent and rift- area off western Mexico at 21 N. Proc. Biol. Soc. Wash. 1985, 98, 447-469.

6. Pettibone, M.H. An additional new scale worm (Polychaeta: Polynoidae) from the hydrothermal rift area off western Mexico at 21 N. Proc. Biol. Soc. Wash. 1985, 98, 150-157.

7. Pettibone, M.H. A new scale-worm commensal with deep-sea mussels on the Galapagos hydrothermal vent (Polychaeta: Polynoidae). Proc. Biol. Soc. Wash. 1984, 97, 226-239.

8. Desbruyères, D.; Laubier, L. Exploitation of a concentrated organic matter source in the deep sea: Role of a new polychaetous annelid C. r. hebd. Séanc. Acad. Sci. Paris 1988, 307, 329-336.

9. Miura, T. Two new scale-worms (Polynoidae: Polychaeta) from the Lau back-arc and north Fiji basins, South Pacific Ocean. Proc. Biol. Soc. Wash. 1994, 107, 532-543.

10. Hourdez, S.; Jouin-Toulmond, C. Functional anatomy of the respiratory system of Branchipolynoe species (Polychaeta, Polynoidae), commensal with Bathymodiolus species (Bivalvia, Mytilidae) from deep-sea hydrothermal vents. Zoomorphology 1998, 118, 225-233. [CrossRef]

11. Desbruyères, D.; Gaill, F.; Laubier, L.; Fouquet, Y. Polychaetous annelids from hydrothermal vent ecosystems: An ecological overview. Bull. Biol. Soc. Wash. 1985, 6, 103-116.

12. Colaço, A.; Dehairs, F.; Desbruyères, D. Nutritional relations of deep-sea hydrothermal fields at the Mid-Atlantic Ridge: A stable isotope approach. Deep Sea Res. Part I 2002, 49, 395-412. [CrossRef]

13. Britayev, T.A.; Krylova, E.M.; Martin, D.; Cosel, R.; Aksiuk, T.S. Symbiont-host interraction in the association of the scaleworm Branchipolynoe aff. seepensis (Polychaeta: Polynoidae) with the hydrothermal mussel Bathymodiolus spp. (Bivalvia: Mytilidae). InterRidge News 2003, 12, 13-16.

14. Britayev, T.A.; Martin, D.; Krylova, E.M.; von Cosel, R.; Aksuik, T.S. Life-history traits of the symbiotic scale-worm Branchipolynoe seepensis and its relationships with host mussels of the genus Bathymodiolus Hydrothermal Vents. Mar. Ecol. 2007, 28, 36-48. [CrossRef]

15. Ward, M.; Shields, J.; Van Dover, C. Parasitism in species of Bathymodiolus (Bivalvia: Mytilidae) mussels from deep-sea seep and hydrothermal vents. Dis. Aquat. Org. 2004, 62, 1-16. [CrossRef] [PubMed] 
16. Van Dover, C.; Trask, J.; Gross, J.; Knowlton, A. Reproductive biology of free-living and commensal polynoid polychaetes at the Lucky Strike hydrothermal vent field (Mid-Atlantic Ridge). Mar. Ecol. Prog. Ser. 1999, 181, 201-214. [CrossRef]

17. Jollivet, D.; Empis, A.; Baker, M.C.; Hourdez, S.; Comtet, T.; Jouin-Toulmond, C.; Desbruyères, D.; Tyler, P.A. Reproductive biology, sexual dimorphism, and population structure of the deep sea hydrothermal vent scale-worm, Branchipolynoe seepensis (Polychaeta: Polynoidae). J. Mar. Biol. Assoc. UK 2000, 80, 55-68. [CrossRef]

18. Gaudron, S.M.; Hourdez, S.; Olu, K. Aspects on gametogenesis, fertilization and embryogenesis of two deep-sea polychaetes from Eastern Atlantic cold seeps. Deep Sea Res. Part I 2017, 129, 59-68. [CrossRef]

19. Pettibone, M.H. A new scale-worm commensal with deep-sea mussels in the seep-sites at the Florida escarpment in the eastern Gulf of Mexico (Polychaeta: Polynoidae: Branchipolynoinae). Proc. Biol. Soc. Wash. 1986, 99, 444-451.

20. Miura, T.; Hashimoto, J. Two new branchiate scale-worms (Polynoidae: Polychaeta) from the hydrothermal vent of the Okinawa Trough and the volcanic seamount off Chichijima Island. Proc. Biol. Soc. Wash. 1991, 104, 166-174.

21. Zhou, Y.; Zhang, D.; Lu, B.; Wang, C. Description of a new branchiate scale-worm (Polychaeta: Polynoidae) from the hydrothermal vent on Southwest Indian Ocean Ridge. Zootaxa 2017, 4282, 123-134. [CrossRef]

22. Fisher, C.; Childress, J.; Arp, A.; Brooks, J.; Distel, D.; Favuzzi, J.; Felbeck, H.; Hessler, R.; Johnson, K.; Kennicutt, M.; et al. Microhabitat variation in the hydrothermal vent mussel, Bathymodiolus thermophilus, at the Rose Garden vent on the Galapagos Rift. Deep. Sea Res. Part A. Oceanogr. Res. Pap. 1988, 35, 1769-1791. [CrossRef]

23. Chevaldonné, P.; Jollivet, D.; Feldman, R.A.; Desbruyères, D.; Lutz, R.A.; Vrijenhoek, R.C. Commensal scale-worms of the genus Branchipolynoe (Polychaeta: Polynoidae) at deep-sea hydrothermal vents and cold seeps. Cah. De Biol. Mar. 1998, 39, 347-350.

24. Hurtado, L.A.; Lutz, R.A.; Vrijenhoek, R.C. Distinct patterns of genetic differentiation among annelids of eastern Pacific hydrothermal vents. Mol. Ecol. 2004, 13, 2603-2615. [CrossRef] [PubMed]

25. Miura, T. Branchipolynoe Pettiboneae Miura \& Hashimoto, 1991. In Handbook of Deep-Sea Hydrothermal Vent Fauna. Denisia 18; Desbruyères, D., Segonzac, M., Bright, M., Eds.; Biologiezentrum der Oberösterreichischen Landesmuseen: Linz, Austria, 2006; p. 231.

26. Sui, J.; Li, X. A new species and new record of deep-sea scale-worms (Polynoidae: Polychaeta) from the Okinawa Trough and the South China Sea. Zootaxa 2017, 4238, 562. [CrossRef] [PubMed]

27. Zhang, Y.; Chen, C.; Qiu, J.W. Sexually Dimorphic Scale Worms (Annelida: Polynoidae) From Hydrothermal Vents in the Okinawa Trough: Two New Species and Two New Sex Morphs. Front. Mar. Sci. 2018, 5, 112. [CrossRef]

28. Miura, T. Branchipolynoe Pettiboneae Miura \& Hashimoto, 1991. In Handbook of Deep-Sea Hydrothermal Vent Fauna; Desbruyères, D., Segonzac, M., Eds.; IFREMER: Brest, France, 1997; p. 55.

29. Van Dover, C.L.; Humphris, S.E.; Fornari, D.; Cavanaugh, C.M.; Collier, R.; Goffredi, S.K.; Hashimoto, J.; Lilley, M.D.; Reysenbach, A.L.; Shank, T.M.; et al. Biogeography and ecological setting of Indian Ocean hydrothermal vents. Science 2001, 294, 818-823. [CrossRef] [PubMed]

30. Copley, J.T.; Marsh, L.; Glover, A.G.; Hühnerbach, V.; Nye, V.E.; Reid, W.D.K.; Sweeting, C.J.; Wigham, B.D.; Wiklund, H. Ecology and biogeography of megafauna and macrofauna at the first known deep-sea hydrothermal vents on the ultraslow-spreading Southwest Indian Ridge. Sci. Rep. 2016, 6, 39158. [CrossRef]

31. Faure, B.; Schaeffer, S.W.; Fisher, C.R. Species distribution and population connectivity of deep-sea mussels at hydrocarbon seeps in the Gulf of Mexico. PLoS ONE 2015, 10, e011846019. [CrossRef]

32. Segonzac, M. Les peuplements associés à l'hydrothermalisme océanique du Snake Pit (dorsale médio-atlantique; $23^{\circ} \mathrm{N}, 3480 \mathrm{~m}$ ): composition et microdistribution de la mégafaune. Comptes Rendus Acad. Sci. Paris 1992, 314, 593-600.

33. Desbruyères, D.; Alayse, A.M.; Antoine, E.; Barbier, G.; Barriga, F.; Biscoito, M.; Briand, P.; Brulport, J.P.; Comtet, T.; Cornec, L.; et al. New information on the ecology of deep-sea vent communities in the Azores Triple Junction area: Preliminary results of the Diva 2 cruise (May 31-July 4, 1994). InterRidge News 1994, 3 , 18-19. 
34. Plouviez, S.; Daguin-Thiébaut, C.; Hourdez, S.; Jollivet, D. Juvenile and adult scale worms Branchipolynoe seepensis in Lucky Strike hydrothermal vent mussels are genetically unrelated. Aquat. Biol. 2008, 3, $79-87$. [CrossRef]

35. Daguin, C.; Jollivet, D. Development and cross-amplification of nine polymorphic microsatellite markers in the deep-sea hydrothermal vent polychaete Branchipolynoe seepensis. Mol. Ecol. Notes 2005, 5, 780-783. [CrossRef]

36. Levin, L.A.; Orphan, V.J.; Rouse, G.W.; Rathburn, A.E.; Ussler, W.; Cook, G.S.; Goffredi, S.K.; Perez, E.M.; Waren, A.; Grupe, B.M.; et al. A hydrothermal seep on the Costa Rica margin: middle ground in a continuum of reducing ecosystems. Proc. R. Soc. B Biol. Sci. 2012, 279, 2580-2588. [CrossRef] [PubMed]

37. Levin, L.A.; Mendoza, G.F.; Grupe, B.; Gonzalez, J.P.; Jellison, B.; Rouse, G.W.; Thurber, A.R.; Waren, A. Biodiversity on the rocks: Macrofauna inhabiting authigenic carbonate at Costa Rica methane seeps. PLoS ONE 2015, 10, e0131080. [CrossRef] [PubMed]

38. Folmer, O.; Black, M.; Hoeh, W.R.; Lutz, R.A.; Vrijenhoek, R.C. DNA primers for amplification of mitochondrial cytochrome c oxidase subunit I from diverse metazoan invertebrates. Mol. Mar. Biol. Biotech. 1994, 3, 294-299.

39. Palumbi, S.R. Nucleic Acids II: The Polymerase Chain Reaction. In Molecular Systematics; Hillis, D.M., Moritz, C., Mable, B.K., Eds.; Sinauer Associates: Sunderland, MA, USA, 1996; pp. 205-247.

40. Nygren, A.; Eklöf, J.; Pleijel, F. Arctic-boreal sibling species of Paranaitis (Polychaeta, Phyllodocidae). Mar. Biol. Res. 2009, 5, 315-327. [CrossRef]

41. Glover, A.G.; Goetze, E.; Dhalgren, T.G.; Smith, C.R. Morphology, reproductive biology and genetic structure of the whale-fall and hydrothermal vent specialist, Bathykurila guaymasensis Pettibone, 1989 (Annelida: Polynoidae). Mar. Ecol. 2005, 26, 223-234. [CrossRef]

42. Roy, K.O.L.; Von Cosel, R.; Hourdez, S.; Carney, S.; Jollivet, D. Amphi-Atlantic cold-seep Bathymodiolus species complexes across the equatorial belt. Deep. Sea Res. Part I Oceanogr. Res. Pap. 2007, 54, 1890-1911.

43. Kearse, M.; Moir, R.; Wilson, A.; Stones-Havas, S.; Cheung, M.; Sturrock, S.; Buxton, S.; Cooper, A.; Markowitz, S.; Duran, C.; et al. Geneious Basic: An integrated and extendable desktop software platform for the organization and analysis of sequence data. Bioinformatics 2012, 28, 1647-1649. [CrossRef]

44. Katoh, K.; Standley, D.M. MAFFT Multiple Sequence Alignment Software Version 7: Improvements in Performance and Usability. Mol. Biol. Evol. 2013, 30, 772-780. [CrossRef]

45. Plouviez, S.; Shank, T.M.; Faure, B.; Daguin-Thiebaut, C.; Viard, F.; Lallier, F.H.; Jollivet, D. Comparative phylogeography among hydrothermal vent species along the East Pacific Rise reveals vicariant processes and population expansion in the South. Mol. Ecol. 2009, 18, 3903-3917. [CrossRef] [PubMed]

46. Van Audenhaege, L.; Farinas-Bermejo, A.; Schultz, T.; Van Dover, C.L. An environmental baseline for food webs at deep-sea hydrothermal vents in Manus Basin (Papua New Guinea). Deep Sea Res. Part I 2019, 148, 88-99. [CrossRef]

47. Vaidya, G.; Lohman, D.J.; Meier, R. Sequence Matrix: Concatenation software for the fast assembly of multi-gene datasets with character set and codon information. Cladistics 2011, 27, 171-180. [CrossRef]

48. Stamatakis, A. RAxML version 8: A tool for phylogenetic analysis and post-analysis of large phylogenies. Bioinformatics 2014, 30, 1312-1313. [CrossRef] [PubMed]

49. Silvestro, D.; Michalak, I. raxmlGUI: A graphical front-end for RAxML. Org. Divers. Evol. 2012, $12,335-337$. [CrossRef]

50. Ronquist, F.; Teslenko, M.; Van Der Mark, P.; Ayres, D.L.; Darling, A.; Höhna, S.; Larget, B.; Liu, L.; Suchard, M.A.; Huelsenbeck, J.P. MrBayes 3.2: Efficient Bayesian Phylogenetic Inference and Model Choice Across a Large Model Space. Syst. Biol. 2012, 61, 539-542. [CrossRef] [PubMed]

51. Swofford, D.L. PAUP: Phylogenetic Analysis Using Parsimony (and Other Methods); Version 4; Sinauer Associates: Sunderland, MA, USA, 2002.

52. Darriba, D.; Taboada, G.L.; Doallo, R.; Posada, D. jModelTest 2: More models, new heuristics and parallel computing. Nat. Methods 2012, 9, 772.

53. Guindon, S.; Gascuel, O. A Simple, Fast, and Accurate Algorithm to Estimate Large Phylogenies by Maximum Likelihood. Syst. Biol. 2003, 52, 696-704. [CrossRef]

54. Puillandre, N.; Lambert, A.; Brouillet, S.; Achaz, G. ABGD, Automatic Barcode Gap Discovery for primary species delimitation. Mol. Ecol. 2012, 21, 1864-1877. [CrossRef] 
55. Leigh, J.W.; Bryant, D. POPART: Full-feature software for haplotype network construction. Methods Ecol. Evol. 2015, 6, 1110-1116.

56. Maddison, W.P.; Maddison, D.R. Mesquite: A Modular System for Evolutionary Analysis. Version 3.5. 2018. Available online: http://www.mesquiteproject.org (accessed on 8 June 2018).

57. Lewis, P.O. A Likelihood Approach to Estimating Phylogeny from Discrete Morphological Character Data. Syst. Biol. 2001, 50, 913-925. [CrossRef] [PubMed]

58. Bickford, D.; Lohman, D.J.; Sodhi, N.S.; Ng, P.K.; Meier, R.; Winker, K.; Ingram, K.K.; Das, I. Cryptic species as a window on diversity and conservation. Trends Ecol. Evol. 2007, 22, 148-155. [CrossRef] [PubMed]

59. Peek, A.S.; Gustafson, R.G.; Lutz, R.A.; Vrijenhoek, R.C. Evolutionary relationships of deep-sea hydrothermal vent and cold-water seep clams (Bivalvia: Vesicomyidae): Results from the mitochondrial cytochrome oxidase subunit I. Mar. Biol. 1997, 130, 151-161. [CrossRef]

60. Johnson, S.B.; Warén, A.; Tunnicliffe, V.; van Dover, C.L.; Wheat, C.G.; Schultz, T.F.; Vrijenhoek, R.C. Molecular taxonomy and naming of five cryptic species of Alviniconcha snails (Gastropoda: Abyssochrysoidea) from hydrothermal vents. Syst. Biod. 2015, 13, 278-295. [CrossRef]

61. Borda, E.; Kudenov, J.D.; Chevaldonné, P.; Desbruyères, D.; Blake, J.A.; Fabri, M.C.; Hourdez, S.; Shank, T.M.; Wilson, N.G.; Pleijel, F.; et al. Cryptic species of Archinome (Annelida: Amphinomidae) from hydrothermal vents and cold seeps. Proc. Roy Soc. B 2013, 280, 20131876. [CrossRef] [PubMed]

62. Stiller, J.; Rousset, V.; Pleijel, F.; Chevaldonné, P.; Vrijenhoek, R.C.; Rouse, G.W. Phylogeny, biogeography and systematics of hydrothermal vent and methane seep Amphisamytha (Ampharetidae, Annelida), with descriptions of three new species. Syst. Biodivers. 2013, 11, 35-65. [CrossRef]

63. Halt, M.N.; Kupriyanova, E.K.; Cooper, S.J.B.; Rouse, G.W. Naming species with no morphological indicators: Species status of Galeolaria caespitosa (Annelida, Serpulidae) inferred from nuclear and mitochondrial gene sequences and morphology. Invertebr. Syst. 2009, 23, 205-222. [CrossRef]

64. Nygren, A. Cryptic polychaete diversity: A review. Zool. Scr. 2013, 43, 172-183. [CrossRef]

65. Berriman, J.S.; Ellingson, R.A.; Awbrey, J.D.; Rico, D.M.; Valdés, Á.A.; Wilson, N.G.; Aguilar, A.; Herbert, D.G.; Hirano, Y.M.; Trowbridge, C.D.; et al. A biting commentary: Integrating tooth characters with molecular data doubles known species diversity in a lineage of sea slugs that consume "killer algae". Mol. Phylogenet. Evol. 2018, 126, 356-370. [CrossRef] [PubMed]

66. Meyer, C.P.; Paulay, G. DNA barcoding: Error rates based on comprehensive sampling. PLoS Biol. 2005, 3, 422-431. [CrossRef] [PubMed]

67. Meier, R.; Zhang, G.; Ali, F. The Use of Mean Instead of Smallest Interspecific Distances Exaggerates the Size of the "Barcoding Gap" and Leads to Misidentification. Syst. Biol. 2008, 57, 809-813. [CrossRef] [PubMed]

68. Nygren, A.; Norlinder, E.; Panova, M.; Pleijel, F. Colour polymorphism in the polychaete Harmothoe imbricata (Linnaeus, 1767). Mar. Biol. Res. 2011, 7, 54-62. [CrossRef]

69. O’Dea, A.; Lessios, H.A.; Coates, A.G.; Eytan, R.I.; Restrepo-Moreno, S.A.; Cione, A.L.; Collins, L.S.; de Queiroz, A.; Farris, D.W.; Norris, R.D.; et al. Formation of the Isthmus of Panama. Sci. Adv. 2016, 2, e1600883. [CrossRef] [PubMed]

70. Farris, D.W.; Jaramillo, C.; Bayona, G.; Restrepo-Moreno, S.A.; Montes, C.; Cardona, A.; Mora, A.; Speakman, R.J.; Glascock, M.D.; Valencia, V. Fracturing of the Panamanian Isthmus during initial collision with South America. Geology 2011, 39, 1007-1010. [CrossRef]

71. Rouse, G.W.; Pleijel, F. Polychaetes; Oxford University Press: London, UK, 2001.

(C) 2019 by the authors. Licensee MDPI, Basel, Switzerland. This article is an open access article distributed under the terms and conditions of the Creative Commons Attribution (CC BY) license (http://creativecommons.org/licenses/by/4.0/). 